\title{
Structural and functional patterns of active bacterial communities during aging of harpacticoid copepod fecal pellets
}

\author{
Clio Cnudde ${ }^{1, *}$, Chelmarie Joy Sanchez Clavano ${ }^{1,2}$, Tom Moens $^{1}$, Anne Willems ${ }^{3}$, \\ Marleen De Troch ${ }^{1}$
}

\begin{abstract}
${ }^{1}$ Marine Biology, Department of Biology, Campus Sterre, Ghent University, Krijgslaan 281 —S8, 9000 Ghent, Belgium ${ }^{2}$ College of Fisheries, Mindanao State University - Maguindanao, Dalican, 9601 Datu Odin Sinsuat, Maguindanao, Philippines

${ }^{3}$ Laboratory of Microbiology, Department of Biochemistry and Microbiology, Ghent University, K.L. Ledeganckstraat 35, 9000 Ghent, Belgium
\end{abstract}

\begin{abstract}
Copepod fecal pellet (fp) dissolved organic matter is consumed by free-living bacteria, while particulate matter is degraded by bacteria packed inside the fp ('internal') or attached to the fp surface after colonization from the environment (external). This study analyzed the contribution of 'internal' and external fp bacteria to the active bacterial community associated with the fp from 2 copepod species, Paramphiascella fulvofasciata and Platychelipus littoralis, during $60 \mathrm{~h}$ of fp aging in seawater. Despite early colonization (within 20 to $40 \mathrm{~h}$ ), fp enrichment by seawater bacteria, as deduced from RNA-based DGGE after $60 \mathrm{~h}$, was limited. In contrast, 'internal' bacteria showed high phylotype richness. The majority of 'internal' bacterial phylotypes persisted on aged fp and together represented half of the active bacterial community. Food source strongly impacted 'internal' bacterial diversity, though the exact origin of fp 'internal' bacteria, as either undigested food-associated bacteria or as copepod gut bacteria, could not be unambiguously determined. 'Internal' bacteria of fresh fp showed a high functional diversity (based on Biolog assays) to which Vibrio sp. contributed significantly. In terms of bacterial diversity and functional potential, degradation of copepod fp by 'internal' bacteria is equally as important as degradation by bacteria which colonize fp from the outside.
\end{abstract}

KEY WORDS: Copepod fecal pellet - Fecal pellet degradation - Active bacterial communities · Harpacticoid copepods $\cdot 16 \mathrm{~S}$ rRNA $\cdot$ DGGE $\cdot$ Biolog EcoPlate ${ }^{\mathrm{TM}}$

\section{INTRODUCTION}

Marine copepods assimilate approximately 30 to $60 \%$ of the food they ingest (Thor et al. 2007). Hence a considerable fraction is voided as fecal pellets (fp) and dissolved organic carbon (DOC) (Smetacek 1980, Jumars et al. 1989, Turner 2002, Møller et al. 2003, Olesen et al. 2005). Copepod fp have a high $\mathrm{C}: \mathrm{N}$ ratio compared to the original food (Morales 1987). In terms of quantity and quality, fp may contribute significantly to the pool of particulate and dis- solved detrital carbon in the oceans. Since a substantial part can be recycled (Turner 2002), the carbon contribution of copepod fp to the detrital pool may be $<10 \%$ in neritic environments (Smetacek 1980). Nevertheless, fp are still a high-quality food source for bacteria which, in turn, upgrade the fp quality for metazoan consumers (Johannes \& Satomi 1966). As a result, fp are rapidly degraded in the upper water layers and only a limited fraction reaches the sediment (Smetacek 1980, Urban-Rich et al. 1999, Wassmann et al. 1999, Wexels Riser et al. 2007). No reports 
on the general fate and bacterial degradation rates of benthic copepod fp exist, notwithstanding benthic fp are also rich in bacteria (De Troch et al. 2010) and may even be grazed by harpacticoid copepods (Koski et al. 2005, De Troch et al. 2009, Møller et al. 2011), a process potentially enhancing fp degradation.

Most of the fp organic matter eventually enters the microbial loop (Jacobsen \& Azam 1984, Anderson \& Tang 2010). In addition to protozooplankton, heterotrophic bacteria are important fp degraders (Poulsen \& Iversen 2008). The DOC plume released from the fp immediately after egestion, nurtures the growth of free-living bacteria and protists (Cho \& Azam 1988, Urban-Rich et al. 1999, Thor et al. 2003). Pellet-associated bacteria solubilize the fp content and degrade the surrounding membrane, producing more labile DOC and releasing smaller-sized POC (Jacobsen \& Azam 1984, Roy \& Poulet 1990, Thor et al. 2003). They also lower the fp C:N ratio (Fukami et al. 1981). Zooplankton mediates the turnover of fp through $\mathrm{fp}$ fragmentation (coprorhexy/-chaly), whereby the increase in the fp surface:volume ratio and the reduction in fp sinking rates facilitate bacterial colonization (Noji et al. 1991, Poulsen \& Kiørboe 2005, Reigstad et al. 2005, Iversen \& Poulsen 2007, Wexels Riser et al. 2007).

The metabolic activity of the bacterial flora associated with copepod $\mathrm{fp}$ is higher than that of free-living seawater bacteria (Tang 2001, Thor et al. 2003). Bacteria may colonize fp from the environment (external activity) (Honjo 1976, Turner 1979, Jacobsen \& Azam 1984, Delille \& Razouls 1994), but may also be delivered by the copepod itself as gut bacteria or transient, digestion-resistant bacteria packed within the pellet (internal activity) (Lawrence et al. 1993, De Troch et al. 2010). Note that 'internal' refers to the origin of the bacteria but not necessarily to the actual location of their activity, which may extend to the fp surface. A low abundance of 'internal' bacteria, compared to the strong colonization of $\mathrm{fp}$ immediately after egestion (Honjo 1976, Turner 1979), suggests degradation driven from the 'outside-in'. In other cases, however, a high survival of bacteria in copepod guts and a resulting high bacterial abundance inside the fp (Lawrence et al. 1993) has been observed, along with limited bacterial abundance on the fp exterior (Gowing \& Silver 1983), supporting the idea of 'inside-out' degradation.

To obtain more insight into the importance of the 'internal' and external fractions of active bacteria during the degradation process of $\mathrm{fp}$ of benthic copepods, we investigated successive changes in the structure of bacterial communities during $60 \mathrm{~h}$ aging of $\mathrm{fp}$ in natural seawater. Immediately after egestion, fp exclusively contain copepod-associated bacteria. These 'internal' fp bacteria can comprise enteric bacteria ('resident') as well as undigested food bacteria that survived gut passage ('transient'). If, shortly after egestion, fp become enriched in external bacteria, freshly produced and degrading fp are expected to show a clear divergence in the composition of their active bacterial community. In addition, a shift in bacterial community composition may be accompanied by a shift in the functioning of the bacterial community. Genetic and metabolic community profiling of the bacterial communities associated with fp of different ages were achieved by means of RNA-based denaturing gradient gel electrophoresis (DGGE) and Biolog EcoPlate ${ }^{\mathrm{TM}}$ carbon substrate utilization assays, respectively.

We focused on the following questions:

(1) Is there an important change in the structure of the active bacterial community during fp aging? Since bacterial attachment to copepod fp occurs within the first few hours, followed by bacterial division on the fp surface (Jacobsen \& Azam 1984), we hypothesize that the 'internal' bacterial community typical of freshly egested fp will rapidly (within hours) be replaced by, or at least become strongly enriched with, external bacteria.

(2) Do the 'internal' bacteria originate from the consumed food source or from the copepod's intestinal flora?

(3) Is there a divergence in bacterial community functionality (metabolic capabilities) of freshly produced versus aged fp? Gowing \& Silver (1983) suggested that 'internal' fp bacteria may be metabolically different from bacteria on the exterior of the fp.

\section{MATERIALS AND METHODS}

\section{Extraction of harpacticoid copepods and gut clearance}

The benthic copepod species Platychelipus littoralis (family Laophontidae) and Paramphiascella fulvofasciata (family Miraciidae) (henceforth referred to by their genus names) were used for fp production. Platychelipus was collected from an intertidal creek in the Paulina salt marsh in the polyhaline reach of the Westerschelde estuary (SW Netherlands, 51 ${ }^{\circ} 20^{\prime}$ $\left.55.4^{\prime \prime} \mathrm{N}, 3^{\circ} 43^{\prime} 20.4^{\prime \prime} \mathrm{E}\right)$. Specimens were extracted from the silty sediment by rinsing over a $250 \mu \mathrm{m}$ sieve and subsequent handpicking under a stereomicro- 
scope using a Pasteur pipet. Paramphiascella was handpicked from a laboratory batch culture, originating from an intertidal area in Helgoland (Germany), reared in $1 \mathrm{l}$ glass beakers with artificial seawater (ASW, salinity ca. 32, Instant Ocean ${ }^{\circledR}$ salt, Aquarium Systems), and fed a diet mainly consisting of the cultured benthic diatom Seminavis robusta. S. robusta was obtained from the diatom culture collection of the Laboratory for Protistology and Aquatic Ecology (Ghent University). Diatom cells were grown nonaxenically in cell tissue culture flasks with $f / 2$ culture medium (Guillard 1975) based on autoclaved ASW (salinity 28) and under the same incubation conditions as the copepods, i.e. at $15^{\circ} \mathrm{C}$ under a $12 \mathrm{~h}$ light:12 $\mathrm{h}$ dark regime. Diatom cultures were kept in exponential growth phase, and the $f / 2$ medium was refreshed regularly.

Batches of copepods (1500 to 2500 specimens) were washed multiple times by sequentially transferring specimens into sterilized ASW (salinity 28, $0.2 \mathrm{~mm}$ filter sterilized and autoclaved), in order to remove loosely attached bacteria and particles adhering to the copepods. The batches comprised adult specimens only and consisted of a randomly sorted mixture of males and females representing the male to female ratio from the field or from the copepod culture. Subsequently, copepods were placed in Petri dishes filled with sterilized ASW (52 mm diameter, 150 copepods per dish) in a climate room at $15^{\circ} \mathrm{C}$ (near in situ temperature) and with a $12 \mathrm{~h}$ light: $12 \mathrm{~h}$ dark regime for $24 \mathrm{~h}$ to allow gut clearance. The same temperature and light conditions were applied throughout this study for laboratory feeding of copepods, fp production and fp aging. The overall preparation of a batch of copepods (isolation, washing and placing in ASW-filled dishes) was completed within ca. 4 to $8 \mathrm{~h}$. The released gut content of Platychelipus specimens, or 'natural fp' (sample notation: nat), composed of food ingested prior to copepod capture, was sampled for bacterial analysis. After $24 \mathrm{~h}$, the natural $\mathrm{fp}$ of Platychelipus were collected from all Petri dishes. All these freshly egested fp were pooled, and the batch of $\mathrm{fp}$ was processed and aged as described further for laboratory fp.

\section{Grazing, fecal pellet production and fecal pellet degradation}

Laboratory fp (sample notation: lab) of the 2 benthic copepod species were obtained by feeding copepods cultured Seminavis robusta diatom cells (Strain $85 \mathrm{~A}$, about $35 \mu \mathrm{m}$ in length), followed by gut clear- ance in sterilized ASW. For this, field-caught and cultured copepods with emptied guts were allowed to graze for $1 \mathrm{~d}$ in sterilized ASW-filled Petri dishes containing $S$. robusta cells ad libitum $\left(>3 \times 10^{3}\right.$ cells). Copepods retrieved from the diatom Petri dishes were rapidly and thoroughly washed with ASW and placed in clean ASW-filled dishes for a $24 \mathrm{~h}$ defecation period as described above. Freshly egested fp were harvested within $24 \mathrm{~h}$ after egestion using an eyed needle and were transferred to sterilized ASW a few times to remove loosely attached bacteria. The freshly egested $\mathrm{fp}$ were not exposed to natural seawater; thus, the associated active bacteria originated exclusively from the copepod, either as transient (undigested) food-associated bacteria or as resident bacteria from the copepod gut or exoskeleton. The batch of fresh fp was split into 4 smaller batches: one batch was used immediately for preparing a sample of fresh $\mathrm{fp}$, representing the 'internal' fp bacteria, and the other 3 were independently aged in Petri dishes filled with natural seawater (NSW) under the same conditions (12 h light: $12 \mathrm{~h}$ dark and $15^{\circ} \mathrm{C}$ ) for 20,40 and $60 \mathrm{~h}$, respectively. The natural seawater was first filtered over a $2.0 \mu \mathrm{m}$ pore-size filter to remove suspended organic particles and protists, but not the free-living bacteria. From 1 batch of fresh $\mathrm{fp}$, 4 samples were obtained (fresh fp and 20, 40 and $60 \mathrm{~h}$ aged fp) (unless fp yield was too low); these were further analyzed with DGGE. Replicated fp samples originated from subsequent fp collection actions, using 1500 to 2500 newly harvested copepods (Table S1 in the Supplement at www.int-res.com/ articles/suppl/a071p025_supp.pdf, biological replicates), namely 3 Platychelipus copepod batches and 2 Paramphiascella copepod batches. However, due to a low fp production by Platychelipus, $<3$ replicates of fp samples were included (Table S1). From each harvest, $S$. robusta and NSW were also sampled (see 'Sample preparation for bacterial analysis').

Similarly, a second series of setups with Platychelipus and Paramphiascella was used to sample fp for metabolic profiling by means of Biolog EcoPlate ${ }^{\mathrm{TM}}$ assays. In contrast to the series for DGGE analysis, no successive fp degradation samples were prepared. Priority was given to obtaining replicate samples of the fresh $\mathrm{fp}$ and $60 \mathrm{~h}$ aged fp originating from the same fp batch (technical replicates, Table S1), since the strongly diluted bacterial inoculates $(1.8 \mathrm{ml}$, see following subsection) for Biolog EcoPlate ${ }^{\mathrm{TM}}$ analysis may cause variability in the carbon source utilization patterns (Garland \& Lehman 1999). Here as well, $S$. robusta, NSW and copepods were screened on EcoPlates alongside fp. 


\section{Sample preparation for bacterial analyses}

Each fp sample was composed of $100 \mathrm{fp}$, collected in a $2 \mathrm{ml}$ Eppendorf tube containing $200 \mu \mathrm{l}$ of sterilized ASW. Due to the low bacterial abundances of fresh fp on the fp exterior (Gowing \& Silver 1983) and the potential lower efficiency of extracting the 'internal' fp bacteria, extracted RNA concentrations were low (in the range of 0 to $5 \mathrm{ng} \mathrm{hl}^{-1}$, i.e. around the lower detection limit of NanoDrop 2000), and cDNA transcription results from preliminary tests were negative. Hence samples of fresh fp were incubated another $24 \mathrm{~h}$ to allow 'internal' bacteria to proliferate while avoiding the risk of contamination with new bacterial strains.

To assess the origin of fp bacteria based on DGGE profiling, aliquots of the Seminavis robusta culture and the filtered NSW were sampled during setups. Copepod samples, consisting of 3 pooled Platychelipus or Paramphiascella specimens, were collected after laboratory feeding on $S$. robusta. Some additional copepods (5 to 10 adults) were collected after laboratory feeding followed by gut clearance. Bacterial analysis of the latter thus represented the resident copepod bacterial flora and/or bacteria associated with the exoskeleton. Samples for bacterial RNA extraction were centrifuged at high speed (ca. 19000 $\times g, 15 \mathrm{~min}$ ); the supernatant was removed, and the 'dry' sample was 'flash'-frozen in liquid nitrogen and stored at $-80^{\circ} \mathrm{C}$ until further analysis.

Samples of fp, Seminavis robusta, NSW and copepods (only with emptied gut) for the EcoPlates ${ }^{\mathrm{TM}}$ assays were all diluted with sterilized ASW to a final volume of $1.8 \mathrm{ml} \mathrm{ASW}$, the volume needed to fill 32 EcoPlate wells with $55 \mu \mathrm{l}$ each, and homogenized for $1 \mathrm{~h}$ at $200 \mathrm{rpm}$ using a mechanical shaker to detach bacteria. Samples were centrifuged at low speed (30 $\times g$ for $1 \mathrm{~min}$ ) to spin down all organic particles except the bacteria. The supernatant with suspended living bacteria was immediately inoculated into the EcoPlate (see section 'Carbon substrate utilization'). An overview of all samples analyzed is given in Table S1.

\section{RNA-based DGGE fingerprinting}

The diversity of active bacteria was profiled by PCR-DGGE of the 16S rRNA of the active bacterial community (Anderson \& Parkin 2007). Total RNA extraction from fp, Seminavis robusta and copepod samples was performed using the NucleoSpin ${ }^{\circledR}$ RNA XS Kit (Macherey-Nagel) developed for small
RNA amounts. In addition to chemical cell lysis following the manufacturer's protocol, $3 \times 30 \mathrm{~s}$ of mechanical disruption with a bead beater at $30 \mathrm{~Hz}$ was included (silicon beads, $1.0 \mathrm{~mm}$ ). For this purpose, the recommended volumes of the kit reagents were consistently doubled, respecting manufacturer's reagent ratios. After on-column DNase treatment, RNA was eluted twice in $10 \mu \mathrm{l}$ nuclease-free water to increase RNA yield. An additional DNA digestion in the RNA eluate was done using TURBO $^{\text {TM }}$ DNase (Ambion) with incubation at $37^{\circ} \mathrm{C}$ for $1 \mathrm{~h}$. TURBO ${ }^{\mathrm{TM}}$ DNase was deactivated afterwards by adding EDTA (15 mM final concentration), followed by a $10 \mathrm{~min}$ incubation at $75^{\circ} \mathrm{C}$. Reverse transcription of RNA to CDNA was performed with the Sensiscript ${ }^{\circledR}$ Reverse Transcription Kit (Qiagen) using the 2-tube method, i.e. cDNA synthesis and cDNA amplification in separate tubes. Prior to cDNA synthesis, RNA extracts were checked to assure they were DNA-free. All RNA extracts were subjected to the polymerase chain reaction (PCR) method (identical to the PCR for amplification of the V3 region of cDNA, see below). No DNA bands were observed on a $1 \%$ agarose gel $(20 \mathrm{~min}, 100 \mathrm{~V})$. For cDNA synthesis by reverse transcription (RT), preparation of the master mix and performance of the RT reaction were executed following the manufacturer's recommendations, using $10 \mu \mathrm{M}$ random hexamer primer (Fermentas,Thermo Scientific), 10 units RNase inhibitor (Qiagen) per reaction, and $1 \mu \mathrm{l}$ of RNA template. From the cDNA, the variable $\mathrm{V}_{3}$ region of the 16S rRNA gene was amplified by PCR, using the universal bacterial primer set $357 \mathrm{f}$ and 518r (Yu \& Morrison 2004) (Sigma Aldrich) with a GC-clamp coupled to the forward primer (Temmerman et al. 2003). The $50 \mu \mathrm{l} \mathrm{PCR} \mathrm{mixture} \mathrm{was}$ prepared with $2 \mu \mathrm{l}$ cDNA template as in Temmerman et al. (2003), but instead of $\mathrm{MgCl}_{2}$ and Taq

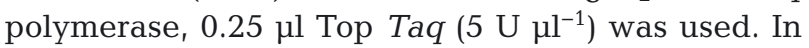
order to increase amplification specificity and reduce the formation of spurious byproducts, a touchdown PCR (Don et al. 1991) was applied using an Eppendorf Thermal Cycler. After 5 min denaturation at $94^{\circ} \mathrm{C}$, the touchdown PCR was performed during 10 cycles including $30 \mathrm{~s}$ denaturing at $94^{\circ} \mathrm{C}$, $30 \mathrm{~s}$ annealing starting at $61^{\circ} \mathrm{C}$ with a $0.5^{\circ} \mathrm{C} \mathrm{cycle}^{-1}$ decrement (until $56^{\circ} \mathrm{C}$ ), and an extension at $72^{\circ} \mathrm{C}$ for $1 \mathrm{~min}$. In the next 25 cycles of regular PCR, annealing was done at $56^{\circ} \mathrm{C}$, ending with a final extension for $30 \mathrm{~min}$ at $72^{\circ} \mathrm{C}$. A negative control, i.e. PCR mix without addition of template DNA, was included in each PCR. Because of low CDNA yields, all samples were subjected to a second PCR using an identical 
touchdown PCR program but only 10 cycles of regular PCR. PCR products were purified using the Wizard ${ }^{\circledR}$ SV Gel and PCR Clean-Up System (Promega), and cDNA concentration was measured using a NanoDrop ${ }^{\circledR} 2000$ (Thermo Scientific). Furthermore, $600 \mathrm{ng}$ cDNA were analyzed by DGGE using a $8 \%$ (w/v) polyacrylamide gel with a 35 to $70 \%$ urea-formamide gradient (Temmerman et al. 2003) and using the Bio-Rad DCode System (Nazareth, Belgium). DGGE was performed in $1 \times$ TAE buffer for $16 \mathrm{~h}$ at $75 \mathrm{~V}$ and at $60^{\circ} \mathrm{C}$. Gels were stained for 30 min with $1 \times$ SYBR Gold nucleic acid gel stain (Invitrogen) in 1× TAE buffer and digitally visualized using a charge-coupled device camera and the Bio-Rad Quantity One software. On each DGGE gel, 3 lanes were loaded with a reference (on the outer lanes and in the middle of the gel). The reference was composed of $V_{3}$ region amplicons of 11 bacterial strains originating from the sandy and silty sediments from the Paulina salt marsh, and allowed normalization of the fingerprint profiles within and among DGGE gels using the BioNumerics software, Version 5.10 (Applied Maths).

\section{Carbon substrate utilization}

The capacity of fp bacterial communities to metabolize different substrates (functional potential) was assessed by means of Biolog EcoPlates ${ }^{\mathrm{TM}}$ (Biolog Corporation) with a community level physiological profile (CLPP) of ecological communities as output (Insam 1997). Biolog EcoPlates ${ }^{\mathrm{TM}}$ contain 31 ecologically relevant carbon sources and 1 blank well (no substrate) in triplicate. A colorless tetrazolium redox dye attached to the substrates was reduced to a violet formazan as a consequence of substrate oxidation by the inoculated bacteria. Color formation was quantified spectrophotometrically, generating a carbon substrate utilization pattern (CSUP) composed of 31 substrate absorbance values (OD, 'optical density').

Under sterile atmosphere, each $1.8 \mathrm{ml}$ homogeneous bacterial suspension (see 'Sample preparation for bacterial analyses') was distributed over the substrate wells $\left(55 \mu\right.$ well $\left.^{-1}\right)$. The control well was inoculated with sterilized ASW. Absorbance measurements at $595 \mathrm{~nm}$ were done with a VICTOR ${ }^{\mathrm{TM}}$ Multi-label Microplate Reader (Perkin Elmer); 25 measurements of $0.5 \mathrm{~s}$ each were performed in each well on a daily basis. The first reading was executed immediately after inoculation of the plates (Day 0). Plates were incubated at $15^{\circ} \mathrm{C}$ and were measured for 10 to $15 \mathrm{~d}$.
At final reading, $30 \mu \mathrm{l}$ of colored wells were subsampled for screening of bacterial diversity on DGGE, based on DNA as all bacteria were expected to be active. After centrifugation at ca. $19000 \times g$ for $20 \mathrm{~min}$, the supernatant was removed from the tubes, and the remaining pellets were stored at $-20^{\circ} \mathrm{C}$. Total DNA was extracted by alkaline lysis (Baele et al. 2000) using $10 \mu \mathrm{l}$ alkaline lysis buffer and $90 \mu \mathrm{l}$ milliQ water. DNA amplification by PCR was executed as described above and loaded on DGGE. To obtain an impression of the diversity of substrateoxidizing bacteria, DGGE bands were excised for sequencing. DNA was eluted from the gel by $10 \mathrm{~min}$ incubation at $65^{\circ} \mathrm{C}$ in TE $1 \times$ buffer. DNA was purified by re-amplification and separation on DGGE 2 to 5 times to achieve optimal purification. Purified DGGE bands were sequenced by Macrogen Corporation. Sequences were aligned to sequences from the NCBI GenBank database (www.ncbi.nlm.nih.gov) using the BLAST program and analyzed by the DECIPHER chimera check program (Wright et al. 2012). Partial 16S rRNA gene sequences were identified using the Ribosomal Project Database (RPD). Sequences have been deposited in EMBL under Accession Numbers HF955287 to HF 955396.

\section{Data analysis of DGGE fingerprints}

DGGE gels were normalized and analyzed using BioNumerics software (Version 4.61, Applied Maths). Each band within a DGGE pattern represents a bacterial phylotype or OTU (operational taxonomic unit). Variations in band intensities within a pattern suggest differential contributions of phylotypes to the active community. Band intensity reflects the total RNA amount of a phylotype within the fp sample. In contrast to DNA-based DGGE, it is not necessarily an indicator of phylotype cell abundance because it may also in part represent the average cell activity of a phylotype since the activity level is partly reflected by the cellular rRNA content (Kerkhof \& Ward 1993, Milner et al. 2001). OTUs among samples were classified as the same OTU when they were positioned within a $1 \%$ range (of total pattern length) from each other. Variability in the community structure of fresh fp was determined by cluster analysis, using the Pearson's correlation coefficient and the unweighted pair group method with the arithmetic mean (UPGMA) algorithm. Bacterial diversity of differently aged fp was assessed by phylotype richness (number of DGGE bands, $S$ ), Shannon-Wiener diversity index $\left(H^{\prime}\right)$ and Simpson's evenness index $\left(1-\lambda^{\prime}\right)$. The effect 
of fp aging on community composition was investigated by multivariate principal coordinates analysis (PCO). The PCO was constructed using square-roottransformed relative band intensity data and a BrayCurtis resemblance matrix. DGGE bands correlated to PCO axes were assigned by Spearman correlation (70\% threshold).

To quantify the step-wise change in community structure over each $20 \mathrm{~h}$ time period (in percent), moving window analysis of DGGE profiles was applied (Marzorati et al. 2008). Herein, the difference between DGGE profiles of consecutive time points was calculated as 100 - similarity percent using Pearson correlation similarity values, and data were plotted on a time axis. Finally, as a possible indication of the functional organization of ecological communities (Marzorati et al. 2008), species distribution curves or Pareto-Lorenz curves (Lorenz 1905) were constructed. Cumulative band numbers of OTUs ranked from high to low band intensity were plotted on the $x$-axis, and their respective cumulative relative band intensities were represented on the $y$-axis. Changes in community evenness were deduced from the position of the curves in accordance with the theoretical perfect-evenness-line ( $45^{\circ}$ diagonal). The cumulative relative abundance ( $y$-value) of $20 \%$ of the OTUs ( $x$-axis, 0.2 value) can be a measure for high, medium, or low functionally organized communities (Wittebolle et al. 2008).

By comparing Seminavis robusta and copepod DGGE profiles, the origin of fresh fp bacteria ('internal' bacteria) was deduced. Main phylotypes of fresh $\mathrm{fp}$, i.e. with a medium (5 to $10 \%$ relative band intensity) to high ( $>10 \%$ relative band intensity) contribution to the active bacterial community, were considered to persist when their contribution to the community remained $>5$ or $10 \%$ on aged $\mathrm{fp}$.

\section{Data analysis of Biolog EcoPlates ${ }^{\mathrm{TM}}$}

Bacterial metabolic activity rate of $\mathrm{fp}$, Seminavis robusta, copepods and NSW was assessed by the average well color development (AWCD). AWCD is the average of the 31 substrate wells, after correcting OD values for background absorbance by subtracting the OD value of the blank well (Garland \& Mills 1991). Differences in AWCD at final measurement were determined by 1-way ANOVA using sum of squares Type II for unbalanced datasets and respecting the assumption of normality and homogeneity of variances, tested with the Shapiro-Wilk test and Levene test, respectively. To compensate for differences in AWCD among samples of different origin (see 'Results'), owing to unstandardized inoculum densities, samples were compared at a similar AWCD level, generally referred to as the single-time-point approach (Garland 1996). A standard AWCD value of 0.2 was chosen, equal to the lowest observed AWCD among all samples. This AWCD was observed for $\mathrm{fp}$ samples in the present study. This standard value was reached after 10 to $15 \mathrm{~d}$ for fp samples but at different time points for other sample types ( $S$. robusta, copepods, NSW). Analyses were executed on net absorbance values, i.e. OD values corrected for blank well OD and for substrate-specific background noise by subtraction of the substrate OD value at time $T_{0}$ (Nair \& Ngouajio 2012). A positive substrate response was defined by a visually observed well coloration with a net absorbance value $\geq 0.2$. All OD values $<0.2$ were set to zero.

To depict differences in bacterial functional diversity between fresh and aged fp, principal components analysis (PCA) was executed based on normalized OD values. For normalization, OD values were divided by the AWCD (Garland 1996). Significant difference in CSUP between the a priori defined groups of fresh and aged fp was tested with a 1-way ANOSIM for each copepod species separately.

The potential of $\mathrm{fp}$ bacterial assemblages to utilize substrates was further assessed by recording substrate richness $S$, i.e. the number of positive responses per sample. Based on chemical composition, the substrates of EcoPlates belong to 6 substrate guilds (carbohydrates, carboxylic acids, polymers, amino acids, amines and miscellaneous compounds) (Zak et al. 1994). Utilization of each guild was calculated as the number of positive responses within the guild over all replicate samples. The utilized substrate richness per guild was standardized for the number of sample replicates and for substrate guild size since different guilds are composed of a different number of substrates ( 7 carbohydrates, 9 carboxylic acids, 4 polymers, 6 amino acids, 2 amines and 3 miscellaneous compounds). Substrate guilds were equally weighted by using a guild-specific correction factor calculated as the number of substrates within the guild divided by number of substrates of the largest guild (i.e. carboxylic acids, composed of 9 substrates) (Preston-Mafham et al. 2002).

ANOVA analysis was performed using the software package R, Version 2.14.1 (R Development Core Team 2012), and all other analyses were performed in PRIMER v6 with PERMANOVA add-on software (Clarke \& Gorley 2006, Anderson et al. 2008). 


\section{RESULTS}

\section{Active bacterial communities from fresh fp}

Multiple active phylotypes were found on all freshly produced fp (Fig. 1). 'Internal' bacterial communities of $\mathrm{fp}$ differed between the 2 copepod species and their food sources (UPGMA, lowest similarity level $12 \%$ ). The $2 \mathrm{fp}$ samples of cultured Paramphiascella showed a high similarity of $91 \%$, in contrast to the variability observed between fp samples of the field-caught Platychelipus. Paramphiascella fp also contained a lower phylotype richness ( $S=7$ to 9 ) than Platychelipus fp ( $S=7$ to 16$)$. Among the Platychelipus fp, there was no separate grouping according to fp origin (Fig. 1). Firstly, similarity between the natural fp was very low, the 3 samples clustered at the $12 \%$ similarity level. Secondly, laboratory fp showed a similar variability in associated bacteria and clustered closely with a natural fp sample (at the 87, 60 and $93 \%$ similarity levels, respectively) (Fig. 1). Additionally, Platychelipus laboratory fp were not closely clustered with laboratory fp produced by Paramphiascella fed the same Seminavis robusta diet.

We noted an increased similarity between copepod bacteria and Seminavis robusta bacteria after feeding on S. robusta, from 3.2 to $48.2 \%$ for Paramphiascella (Fig. S1a in the Supplement at www.int-res.com/ articles/suppl/a071p025_supp.pdf). After releasing gut content, similarity of copepod-associated bacteria to those associated with the $S$. robusta food source dropped to $15.6 \%$ (Fig. S1a) due to loss of 5 OTUs. Only 2 prominent OTUs remained associated with the copepods, of which the OTU with the highest band intensity was $S$. robusta-related and the other was an original copepod-related OTU. Also for Platychelipus (Fig. S1b), after removal of the gut content, the copepod bacterial flora showed reduced similarity with $S$. robusta, from 49.6 to $31.3 \%$. Due to gut clearance, the copepod bacteria changed drastically for both copepod species. Additionally, for Paramphiascella, comparison of bacteria from copepods obtained from culture and copepods obtained after one time feeding on $S$. robusta showed a pronounced change in copepod flora (Fig. S1a). The origin of $\mathrm{fp}$ bacteria can be traced, and the specific contribution of food bacteria and copepod bacteria to the active bacterial community of fresh fp was deduced by comparison of the DGGE profiles of laboratory fp with those of $S$. robusta and copepods. Of the main fp bacterial phylotypes (contributing $>5 \%$ to the active community), half appeared to originate directly from the food source (Table 1, bold data) since they were shared with $S$. robusta samples and, if present in the copepod, they were lost after gut clearance, e.g. the DGGE band at position $60.9 \%$ (alias Phylotype 18; Fig. 2). For Platychelipus (Table 1a), 4 out of 7 phylotypes were related to the food source, corresponding to $36 \%$ of the total band pattern intensity. For Paramphiascella (Table 1b), 3 out of 6 phylotypes were related to the food source, corresponding to a cumulative OTU abundance of $71.5 \%$. Other phylotypes were found in common for $S$. robusta and copepods after gut clearance (Table 1, italic data), and their exact origin therefore remains uncertain. None of the main fp phylotypes were found uniquely related to the copepod itself.

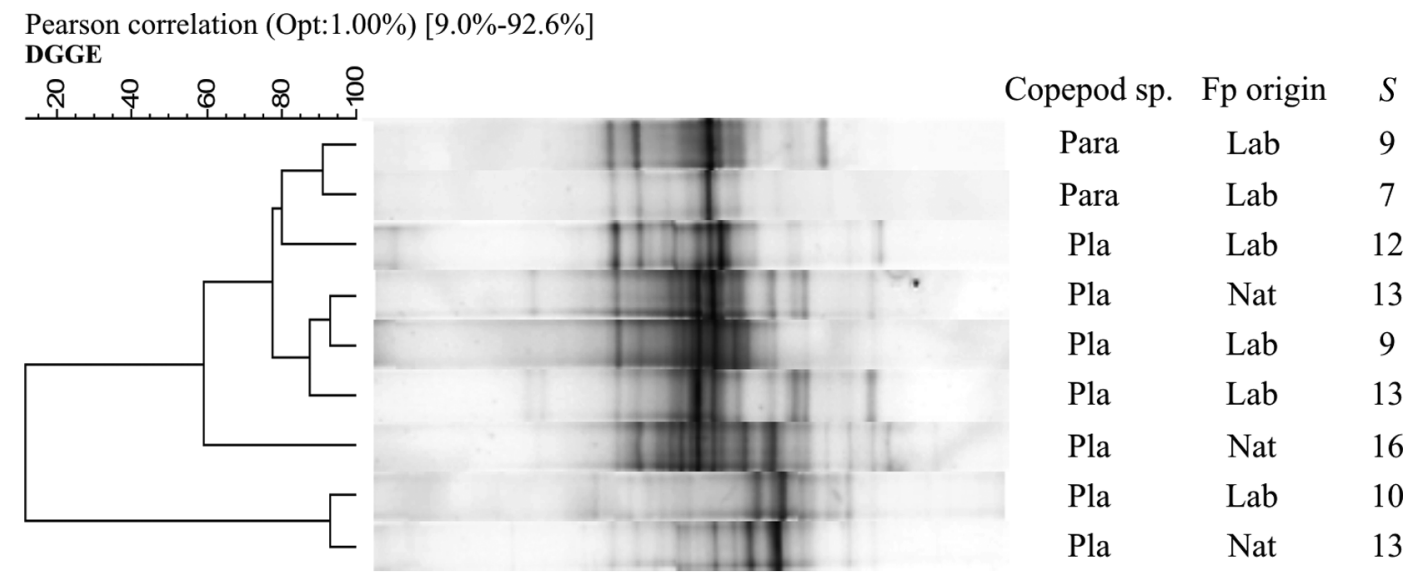

Fig. 1. Similarity between RNA-based denaturing gradient gel electrophoresis (DGGE) profiles of fresh fecal pellets (fp), including natural (nat) and laboratory (lab) fp of the copepods Platychelipus (Pla) and Paramphiascella (Para). S: number of DGGE bands 
Table 1. Origin of 'internal' fecal pellet (fp) bacteria associated with (a) fresh Platychelipus fp and (b) fresh Paramphiascella fp. Overview of main fp DGGE bands (relative band intensity $>5 \%$ ) and their presence in the Seminavis robusta used during the same experimental setup (Food) and in copepods before (Cop - fed) and after gut clearance (Cop-empty); fp bacteria originating from $S$. robusta are in bold; fp bacteria found on both $S$. robusta and copepods are in italics. Data are averaged relative band intensities with standard deviation in parentheses. OTU: operational taxonomic unit

\begin{tabular}{|c|c|c|c|c|c|}
\hline Band (\%) & OTU & $\begin{array}{l}\text { Fecal pellets } \\
\qquad(\mathrm{n}=4)\end{array}$ & $\begin{array}{l}\text { Food } \\
(\mathrm{n}=7)^{\mathrm{a}}\end{array}$ & $\begin{array}{c}\text { Cop_fed } \\
(\mathrm{n}=2)\end{array}$ & $\begin{array}{c}\text { Cop-empty } \\
(\mathrm{n}=2)\end{array}$ \\
\hline \multicolumn{6}{|c|}{ (a) Platychelipus } \\
\hline 39.3 & 7 & $5.0(4.8)$ & $5.9(5.1)$ & $0.9(0.2)$ & \\
\hline 48.2 & 11 & $5.4(5.0)$ & $24.9(9.8)$ & $4.8(1.5)$ & $15.1(3.1)$ \\
\hline 52.4 & 13 & $20.0(15.7)$ & $2.8(6.3)$ & $4.7(1.3)$ & $14.0(3.6)$ \\
\hline 54.0 & 14 & $4.9(9.8)$ & $0.7(1.9)$ & & \\
\hline 55.0 & 15 & $19.4(13.6)$ & $1.3(3.5)$ & & $6.0(2.6)$ \\
\hline 60.9 & 18 & $7.1(11.5)$ & $4.8(4.1)$ & $19.2(3.3)$ & \\
\hline 64.4 & 19 & $10.2(18.7)$ & $7.3(6.7)$ & $19.1(5.1)$ & $4.1(0.9)$ \\
\hline \multicolumn{6}{|c|}{ (b) Paramphiascella } \\
\hline 39.3 & 7 & $7.7(2.3)$ & $26.9(17.1)$ & $11.0(6.7)$ & $6.0(0.4)$ \\
\hline 43.0 & 8 & $10.2(2.1)$ & $12.1(5.3)$ & & \\
\hline 51.0 & 12 & $7.9(10.7)$ & $0.8(1.5)$ & $5.2(4.1)$ & $1.0(0.5)$ \\
\hline 54.0 & 14 & $51.4(13.4)$ & $11.6(7.9)$ & $32.8(13.5)$ & \\
\hline 57.8 & 17 & $9.9(4.2)$ & $10.6(4.0)$ & $13.0(9.4)$ & \\
\hline 59.3 & 42 & $5.1(5.9)$ & & & \\
\hline
\end{tabular}

\section{Shifts in bacterial community structure during aging of fp}

The DGGE gels (Fig. 2) visualize the genetic community structure of the active bacteria of both freshly egested and degraded fp (20, 40 and $60 \mathrm{~h})$. At first glance, numbers of OTUs on degraded fp did not appear much higher than those on fresh $\mathrm{fp}$, though overall OTU richness $S$ was a little higher on all aged fp: fp of Platychelipus increased with 2 to 4 OTUs and fp of Paramphiascella increased with 4 to 7 OTUs, as they aged. Three samples with only 2 bands and an overall weak profile were considered PCR artifacts.

During degradation, the structure of the active bacterial community from fresh fp changed immediately. The PCO (Fig. 3a), explaining $70.3 \%$ of total variation (PCO 1: $48.9 \%$; PCO 2: $21.4 \%$ ), plotted 3 of the fresh fp separately from aged $\mathrm{fp}$, while 2 fresh $\mathrm{fp}$ samples were still positioned close to the $20 \mathrm{~h}$ aged $\mathrm{fp}$. Fresh $\mathrm{fp}$ were located on the negative side of both axes. Seven OTUs were correlated at $>70 \%$ with PCO 1 (OTU 4, 11, 13, 18, 19) or PCO 2 (OTU 7, 14) (OTUs indicated in Fig. 2). Only 1 OTU (OTU 4) was unique for aged $\mathrm{fp}$. The other OTUs were, at least once, part of the fresh fp community. Three of these phylotypes were previously denoted as possibly originating from Seminavis robusta (OTU 7, 14, 18) and 3 were undefined (OTU 11, 13, 19). Furthermore, from these 6 'internal' phylotypes, band intensity of 3 OTUs (OTU $7,11,13$ ) increased or remained fairly constant over time, while 2 OTUs (OTU 18, 19) tended to diminish and 1 (OTU 14) was completely lost within $20 \mathrm{~h}$ of aging in NSW.

Since the majority of aged $\mathrm{fp}$ grouped together in the PCO (Fig. 3a), differences in DGGE profiles between differently aged fp are relatively small, indicating that during aging the bacterial communities did not change systematically over time. Moving window analysis (Fig. 3b) illustrates a pronounced change $(42 \%)$ in the community composition of Platychelipus natural fp with between 20 and $40 \mathrm{~h}$ of incubation in NSW. At the same time, Shannon-Wiener diversity $\left(H^{\prime}\right)$ increased from 1.59 to 1.90 , and community evenness $\left(1-\lambda^{\prime}\right)$ increased from 0.70 to 0.79 (Fig. 2), but there was no clear increase in phylotype richness $(S)$. For Platychelipus laboratory fp, a major change $(62 \%)$ was equally observed in the 20 to $40 \mathrm{~h}$ period or within the first $20 \mathrm{~h}$. The fp of the cultured Paramphiascella showed a prominent change (62\%) within the first $20 \mathrm{~h}$ (Fig. 3b), visible in Fig. 2 by a change in dominance (from OTU 14 to 7 ), a complete loss of OTU 14 and the emergence of new OTUs (OTU 11, 13). Elevated values of diversity indices $S, H^{\prime}$ and $1-\lambda^{\prime}$ after $40 \mathrm{~h}$ (Fig. 2) rather than $20 \mathrm{~h}$ indicate a change in the 20 to $40 \mathrm{~h}$ period. In the fp degradation series of Paramphiascella fp which were missing the 20 and $40 \mathrm{~h}$ aged samples (see Fig. 2), the $60 \mathrm{~h}$ aged fp differed strongly from the fresh $\mathrm{fp}$, but no precise timing of an abrupt change could be determined (Fig. 3a,b). Overall, for all fp the community changes beyond $40 \mathrm{~h}$ of incubation were relatively minor.

The Pareto-Lorenz evenness curves of fresh and aging fp for 2 selected degradation sample series (Fig. $4 \mathrm{a}, \mathrm{b}$ ) are highly similar and strongly convex curves. The change in evenness during fp aging showed no clear trend, except for the lower curves of Platychelipus (Fig. 4a). Over all fp, differing in age and from both copepod species, the $y$-axis values ranged from 0.55 to 0.80 , representative of a medium ( $y$-value $\sim 0.45$ ) to highly ( $y$-value $\sim 0.8$ ) functional organized community (Marzorati et al. 2008). Marzorati et al. (2008) defined functional organization as 

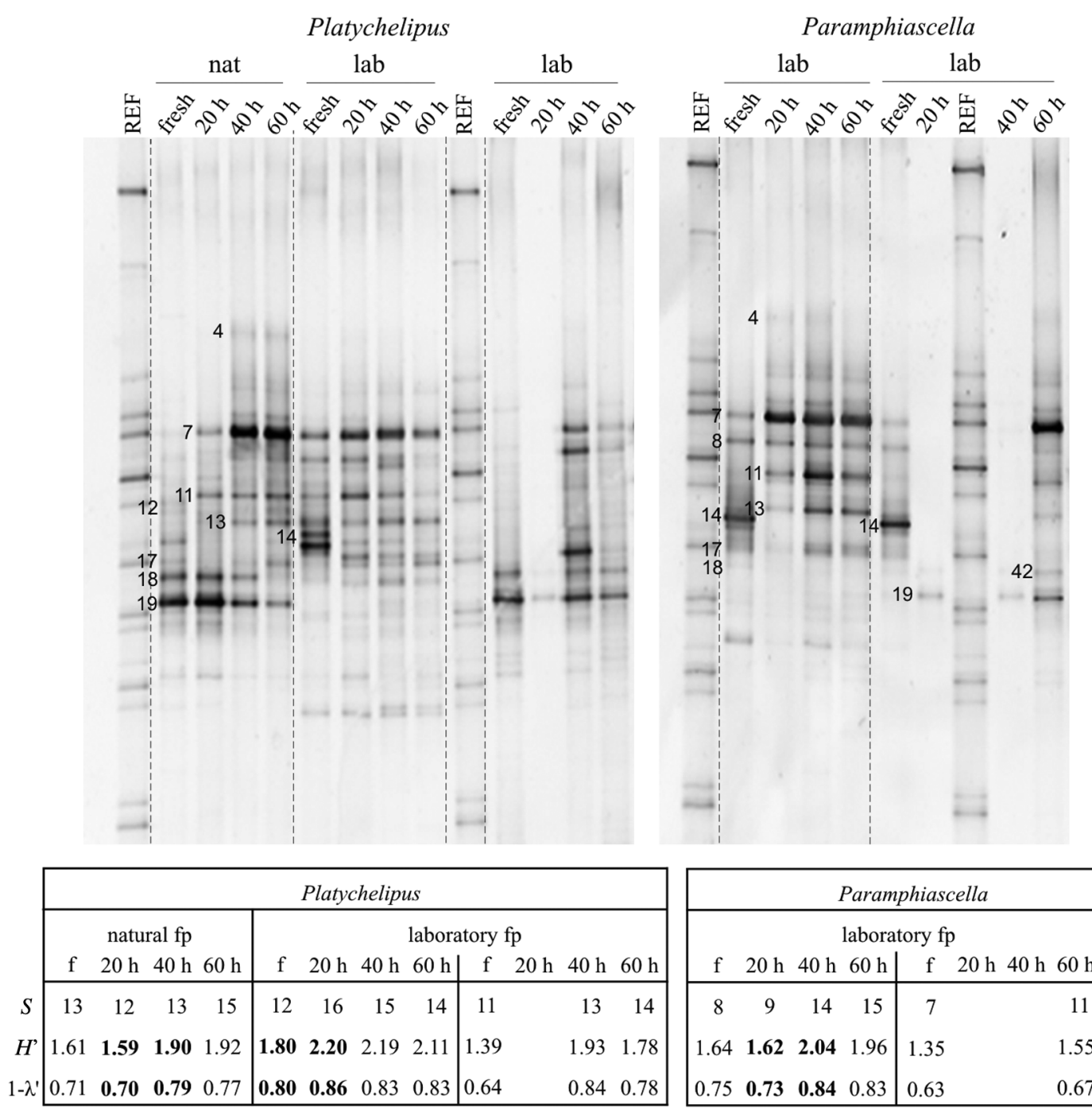

\begin{tabular}{|c|c|c|c|c|c|c|}
\hline \multicolumn{7}{|c|}{ Paramphiascella } \\
\hline \multicolumn{7}{|c|}{ laboratory fp } \\
\hline $\mathrm{f}$ & $20 \mathrm{~h}$ & $40 \mathrm{~h}$ & $60 \mathrm{~h}$ & $\mathrm{f}$ & $20 \mathrm{~h} 40 \mathrm{~h}$ & $60 \mathrm{~h}$ \\
\hline 8 & 9 & 14 & 15 & 7 & & 11 \\
\hline 1.64 & 1.62 & 2.04 & 1.96 & 1.35 & & 1.55 \\
\hline 0.75 & 0.73 & 0.84 & 0.83 & 0.63 & & 0.67 \\
\hline
\end{tabular}

Fig. 2. Bacterial community associated with degrading fecal pellets (fp), from fresh (f) fp to $60 \mathrm{~h}$ aged fp at $20 \mathrm{~h}$ time intervals, visualized by DGGE profiles (unprocessed gels; REF: reference lane) and corresponding indices for diversity (phylotype richness $S$ and Shannon-Wiener index $H^{\prime}$ ) and evenness (Simpson's index $1-\lambda^{\prime}$ ). The time period wherein the community structure of the fp changed the most can be deduced from the change in indices values over time. The strongest change between indices values is indicated in bold. Of very weak banding patterns, no indices were calculated (missing data in the table). Natural (nat) and laboratory (lab) fp originated from Platychelipus and Paramphiascella. Numbers on the gels indicate relevant operational taxonomic units

the ability of a community to organize in an adequate distribution of dominant and resilient microorganisms and to counteract the effect of a sudden stress exposure, e.g. environmental change.

For both Platychelipus and Paramphiascella fp, a number of 'internal' phylotypes of fresh fp still contributed to the active community after $60 \mathrm{~h}$ of aging of the pellet in NSW and thus persisted in the presence of NSW bacteria. For Platychelipus fp (natural and laboratory fp), $66.7 \pm 28.9 \%$ (i.e. 4 OTUs) of the phylotypes with an originally high contribution to the fresh fp community (band intensity $>10 \%$ of the DGGE profile) still contributed $>10 \%$ to the aged community (Table 2a) and thus persisted. From the phylotypes with a relative band intensity of 5 to $10 \%$ or medium contributing phylotypes, another $16.7 \pm$ $28.9 \%$ persisted (i.e. 2 OTUs) (Table 2a). Overall, 'internal' bacteria represented almost half of the $60 \mathrm{~h}$ aged bacterial community, namely $46 \%$ in Platychelipus fp (sum of $40.5 \pm 24.5 \%$ and $5.5 \pm 5.1 \%$, for the $>10 \%$ and the 5 to $10 \%$ contributing OTUs, respectively) and $56 \%$ in Paramphiascella fp (sum of $4.3 \pm$ $2.1 \%$ and $51.9 \pm 23.6 \%$, for the $>10 \%$ and the 5 to $10 \%$ contributing OTUs, respectively) (Table $2 \mathrm{~b}$ ). For the latter, the importance of medium-contributing phylotypes increased during degradation, from 30.7 

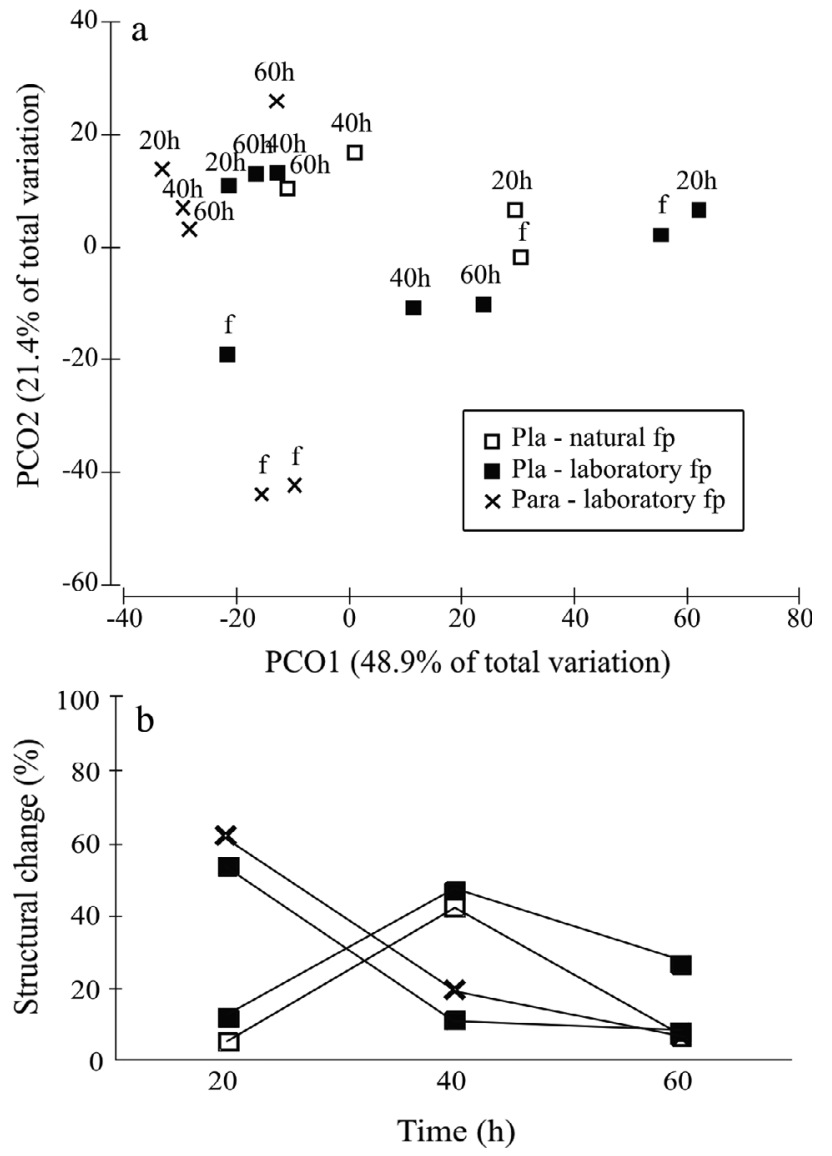

Fig. 3. Successive change in the DGGE profiles of active bacteria during fecal pellet (fp) degradation, from fresh (f) fp to 20,40 and $60 \mathrm{~h}$ aged fp assessed by (a) multivariate principal coordinates analysis (PCO) and (b) by univariate moving window analysis. In the latter, data points indicate the percentage change of the bacterial community that occurred during a $20 \mathrm{~h}$ time period. The DGGE profiles used are presented in Fig. 2. Pla: Platychelipus; Para: Paramphiascella $\pm 5.6 \%$ to $51.9 \pm 23.6 \%$, but the importance of highly contributing 'internal' phylotypes was strongly reduced, from $67.2 \pm 2.9 \%$ to $4.3 \pm 2.1 \%$ (Table $2 b$ ). These results showed that during aging, on all $\mathrm{fp}$, there was an almost even contribution (fifty-fifty) of the original, 'internal' fp phylotypes and other fp phylotypes, supposedly originating from the NSW.

\section{Metabolic potential of fp bacteria}

AWCD (violet coloration) in EcoPlate assays differed among sample types based on inoculum density differences $(\mathrm{p}>0.001)$. NSW showed rapid color development, i.e. with final measurements (after $10 \mathrm{~d}$ ) being 5 to 10 times higher than fp, Seminavis robusta and copepod samples $\left(\mathrm{AWCD}_{\mathrm{NSW}}=1.03\right.$, $\mathrm{AWCD}_{\mathrm{fp}}=0.22, \mathrm{AWCD}_{\text {Seminavis }}=0.14, \mathrm{AWCD}_{\text {copepod }}=$ $0.14 ; \mathrm{N}=3,27,3,9$, respectively; $\mathrm{SD}$ all \pm 0.10 ) (post hoc, all $\mathrm{p}<0.001$ ), as well as having the most complex CSUP (27 out of 31 substrates used). Analyses of CSUPs were executed on an AWCD set-point of approximately 0.20 OD (see 'Materials and methods'). Note that for NSW, where AWCD 0.2 OD is already reached on Day 3, the analyzed CSUPs may not represent the complete metabolic potential of NSW bacteria but may include only the fastest responding substrate reactions. Functional diversity measured by CSUP differed between fresh fp and $60 \mathrm{~h}$ aged fp. In a PCA (Fig. S2 in the Supplement at www.int-res.com/articles/suppl/a071p025_supp.pdf), fresh and aged fp grouped almost separately (PC 1 and PC 2 explaining 41.5 and $23.4 \%$ of the total variation, respectively). The difference in CSUP of fresh
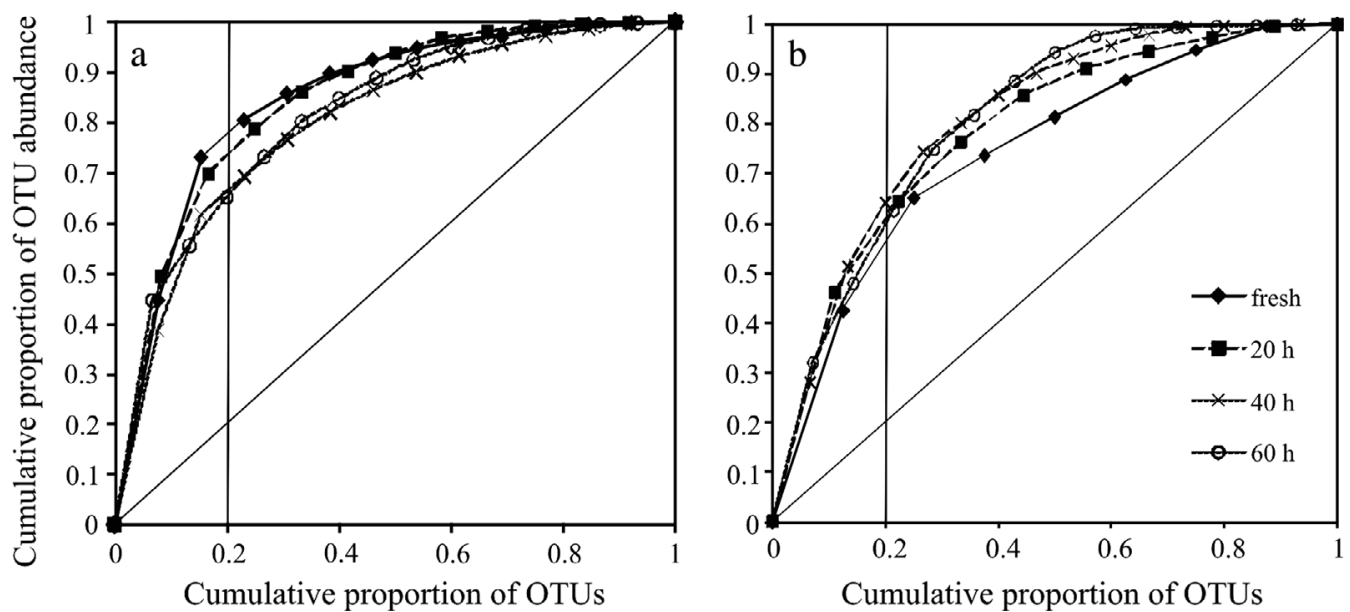

Fig. 4. Pareto-Lorenz curves of active bacterial communities associated with aging: (a) natural Platychelipus fecal pellets and (b) laboratory Paramphiascella fecal pellets. The diagonal line represents perfect evenness. Curves are compared at the 0.2 $x$-axis value 
Table 2. The presence of 'internal' bacteria during fecal pellet (fp) aging: (a) their persistence in aging fp, expressed as the percentage of operational taxonomic units (OTUs) from fresh fp, of which DGGE band intensity in aged communities at least equals the original band intensity in fresh fp bacterial communities and (b) their cumulative contribution to the aged active community, expressed as the summed band intensities of all persisting 'internal' OTUs compared to total DGGE profile intensity (in \%). Standard deviations are in parentheses. 'Internal' bacterial phylotypes are grouped as highly contributing (band intensity $>10 \%$ contribution to the active community) or medium contributing (band intensity 5 to $10 \%$ contribution to the active community) phylotypes according to their initial contribution to the fresh fp bacterial community. Natural (nat) and laboratory (lab) fp of copepods were examined. Bold values mark the overall persistence of internal bacteria (or their contribution to the active community) at the end of the experiment, i.e. after $60 \mathrm{~h}$ of fp aging. Empty cells are missing data due to weak DGGE banding patterns (see also Fig. 2.)

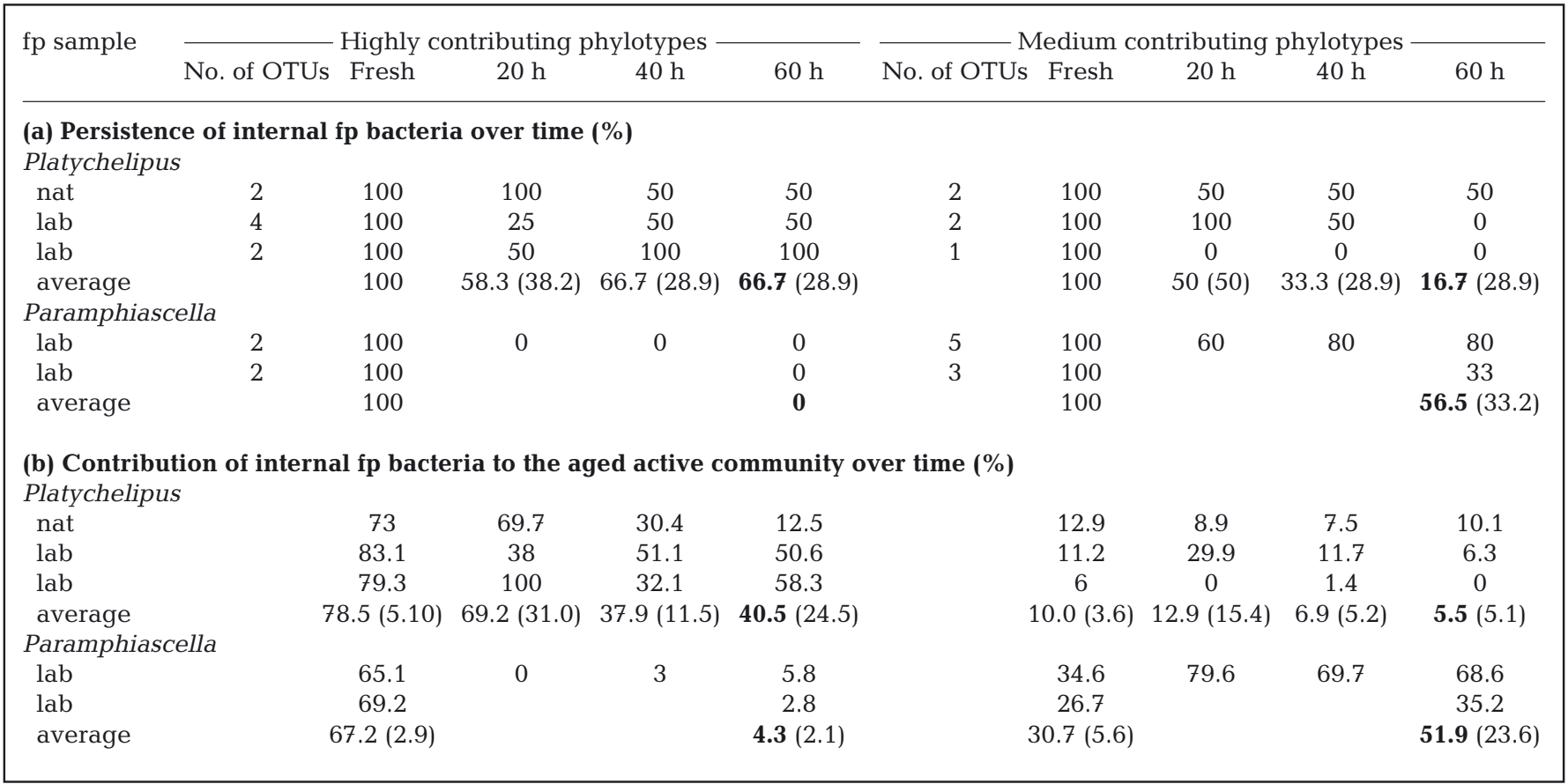

and aged fp was small and insignificant for both Platychelipus (ANOSIM, R $=0.158, \mathrm{p}=0.012$ ) and Paramphiascella (ANOSIM, $\mathrm{R}=-0.125, \mathrm{p}=0.61$ ), respectively, although aged fp samples grouped closely together (except for 1 outlier) while spreading of fresh fp samples was high. This represents a relatively high variability in CSUPs of fresh fp which diminished during fp aging. In the case of Platychelipus, fresh fp bacteria used $7 \pm 2$ substrates $(\mathrm{N}=10)$, while aged $\mathrm{fp}$ bacteria consistently used a lower number of substrates $(S=2 \pm 2, \mathrm{~N}=7$ ) (Fig. 5a,b). Besides substrate richness, substrate OD values being indicative of bacterial metabolic activity (cell activity or cell abundance) - of aged fp samples were generally low while these fp were exposed for $60 \mathrm{~h}$ to free-living seawater bacteria with a higher metabolic potential $(S=7 \pm 2, \mathrm{~N}=3$ ) (Fig. $5 \mathrm{a}, \mathrm{b})$. On the other hand, fresh fp bacteria utilized more substrates than $S$. robusta and copepod bacteria where substrate richness was only $2 \pm 0(\mathrm{~N}=3)$ and $5 \pm 3$ $(\mathrm{N}=8)$, respectively (Fig. 6a,b,c). A reduced substrate utilization pattern of aged fp was not found for Paramphiascella fp (Fig. 5c), where substrate rich- ness $S$ was $7 \pm 3(\mathrm{~N}=6)$ for fresh fp and $8 \pm 6(\mathrm{~N}=2)$ for aged fp.

The most frequently utilized substrates by fp bacteria were (in decreasing order): Tween 80 (19 responses), N-acetyl-D-glucosamine (18 responses), Dmannitol and D-cellobiose (each 15 responses), glycogen (10 responses), $\alpha$-D-lactose (8 responses), Tween 40 and L-threonine (each 7 responses) and Lasparagine and putrescine (each 6 responses). Fp bacteria were able to metabolize all substrate guilds in contrast to bacteria from Seminavis robusta, copepods and NSW (Table S2 in the Supplement at www. int-res.com/articles/suppl/a071p025_supp.pdf). For all sample types carbohydrates and polymers were the main utilized guilds. Laboratory fp bacteria utilized Tween 40 and miscellaneous compounds (pyruvicacid-methyl-ester, D,L- $\alpha$-glycerol phosphate), which were unique for $S$. robusta and copepod CSUPs, respectively, and were not used by seawater bacteria. For NSW, substrate richness increased strongly at higher AWCD readings, but in this study only the fast-responding substrates have been included (Fig. 6d). 
Fresh fp
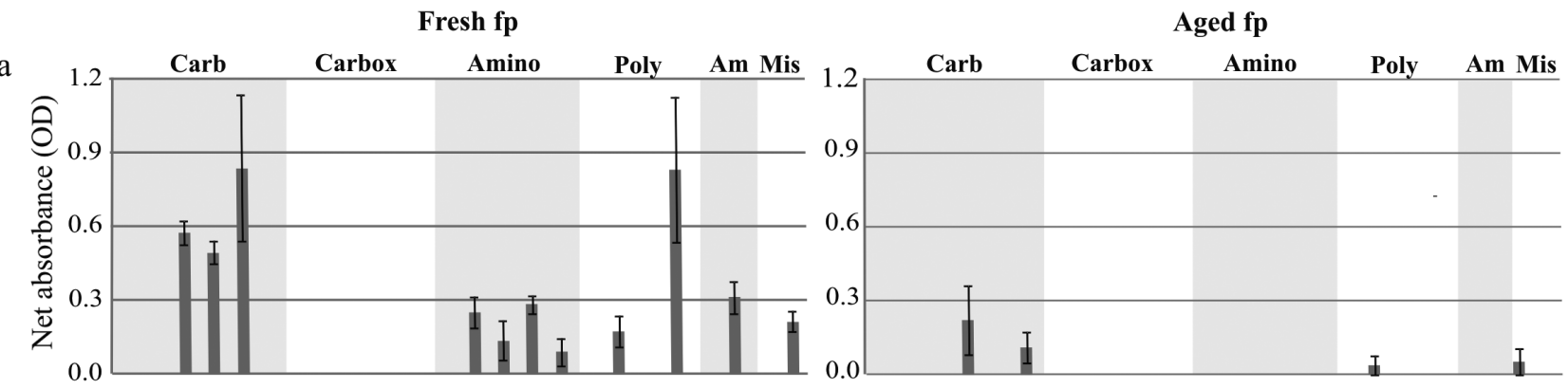

$\mathrm{b}$
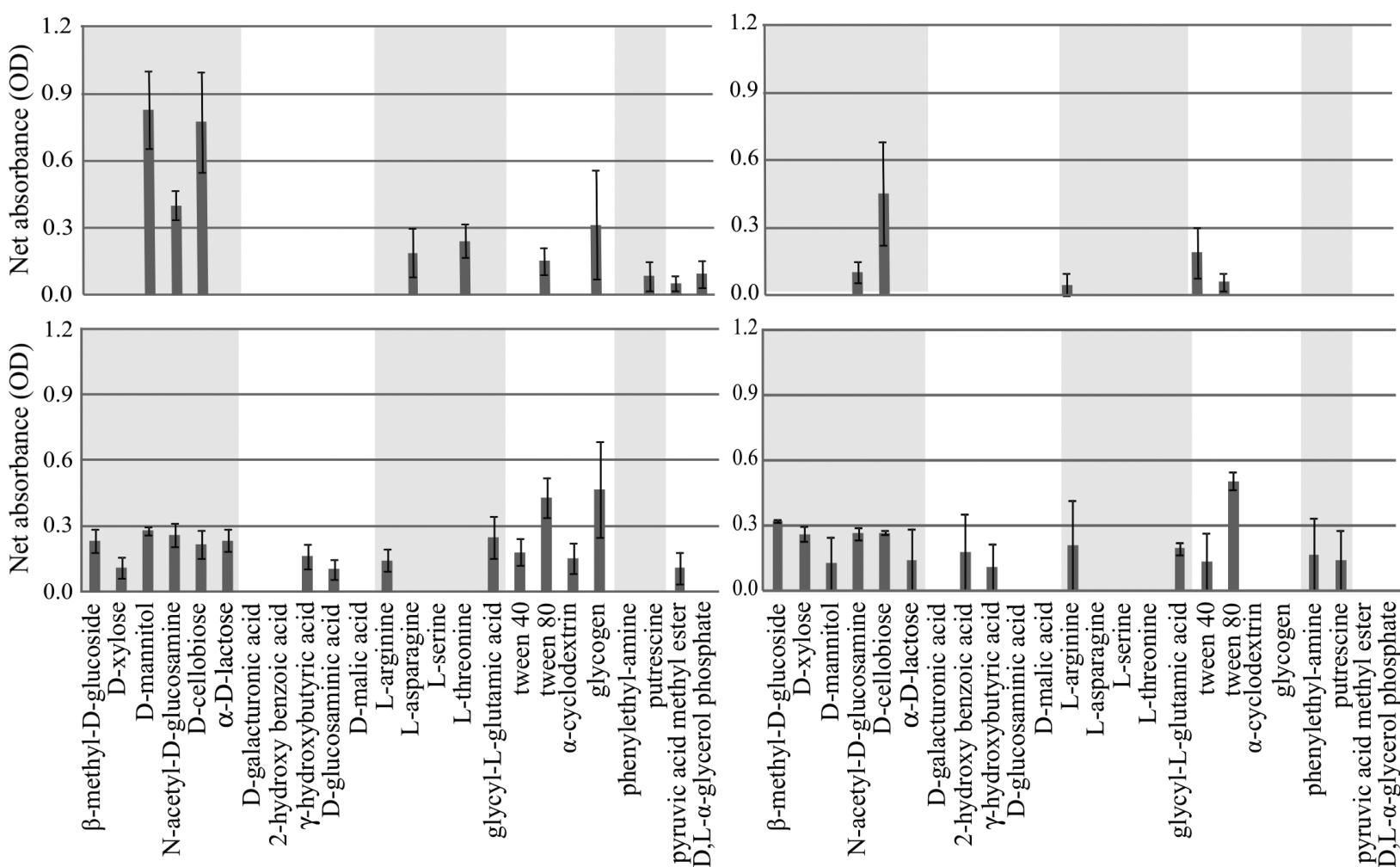

Fig. 5. Carbon substrate utilization patterns of bacteria associated with fresh (left panels) and $60 \mathrm{~h}$ aged (right panels) fecal pellets (fp): (a) natural Platychelipus fp, (b) laboratory Platychelipus fp and (c) laboratory Paramphiascella fp. When the substrate was positive in at least 1 replicate, optical density (OD) values of all replicates were averaged and represented by bars (average \pm SE). Carb: carbohydrates; Carbox: carboxylic acids; Amino: amino acids; Poly: polymers; Am: amines; Mis: miscellaneous

A total of 127 DGGE bands originating from positive wells and covering the entire pattern spread (data not shown) were successfully sequenced. The observed substrate oxidations were realized by fp bacteria belonging predominantly to Gammaproteobacteria and Alphaproteobacteria. Further sequencing revealed the following genera: Pseudomonas, Pseudoalteromonas, Marinomonas, Alcanivorax and Thallassospira for fp of both copepod species. From Platychelipus fp, additional genera were Halomonas, Rhodovulum, Photobacterium and a dominant presence of Vibrio. A few Bacteroidetes (Myroides, Flavobacterium) were retrieved only from Platychelipus fp.

\section{DISCUSSION}

Microbes (protozoa and bacteria) are key degraders of copepod fp. To understand the process of bacterial fp degradation, it is important to investigate the degradation taking place in the interior and on the exterior of the $\mathrm{fp}$.

Many studies have proven the bacterial presence inside copepod fp as well as on the fp exterior (e.g. Gowing \& Silver 1983, Lawrence et al. 1993). Few studies have focused on the metabolic activity of $\mathrm{fp}$ bacteria (Tang et al. 2001, Thor et al. 2003), which is of primary interest for investigating fp degradation, 
a

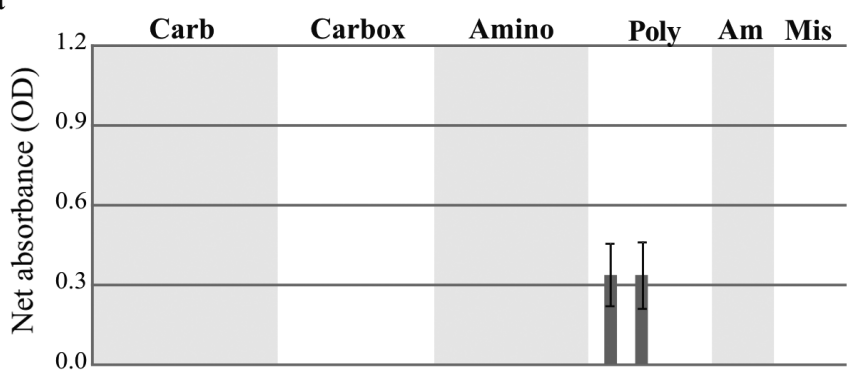

b

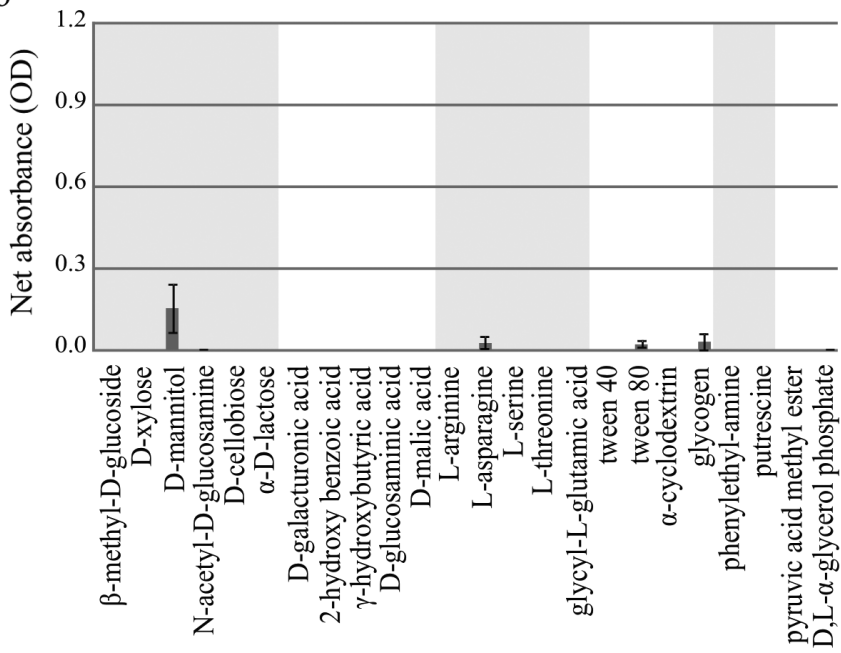

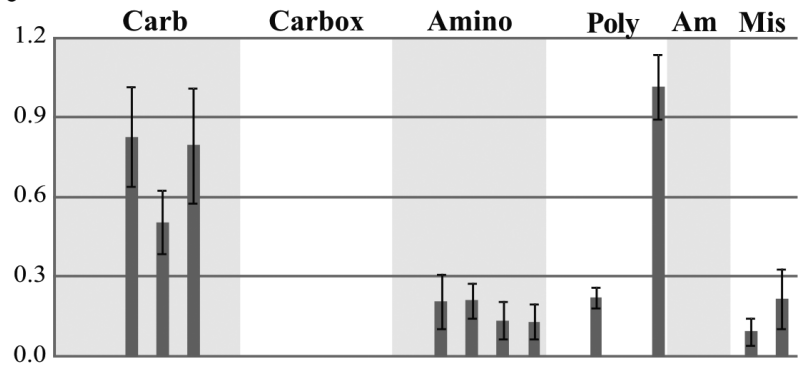

d

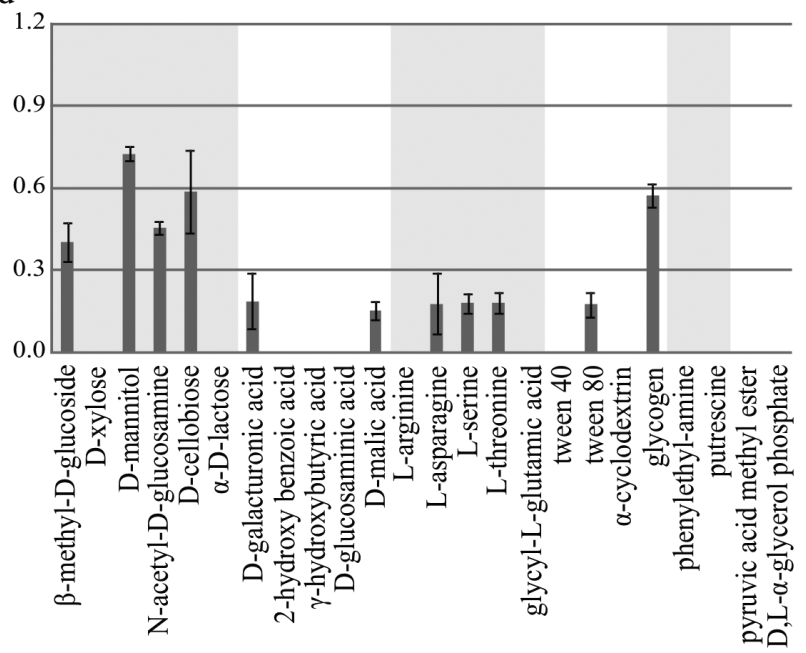

Fig. 6. Carbon substrate utilization patterns of bacteria associated with (a) Seminavis robusta, (b) field-caught Platychelipus copepods, (c) laboratory-fed Platychelipus copepods and (d) natural seawater. When the substrate was positive in at least 1 replicate, optical density (OD) values of all replicates were averaged and represented by bars (average \pm SE). Carb: carbohydrates; Carbox: carboxylic acids; Amino: amino acids; Poly: polymers; Am: amines; Mis: miscellaneous

since intact bacterial cells observed in fp are not necessarily in an active status (viable but dormant, or unviable and harmed during gut passage but without cell lysis). Therefore, this study reports on bacterial fp degradation and the successive role of 'internal' and external bacteria, using RNA-based DGGE and carbon substrate utilization patterns, in which strictly the active fp bacteria are analyzed, thus excluding the fraction of viable but non-active 'internal' bacteria and the bacterial cells which may have died during the degradation process but are still associated with the fp.

\section{Internal fp bacteria}

Assemblages of active bacteria packed within fp were variable in species diversity and abundances and were more diverse for $\mathrm{fp}$ originating from fieldcaught copepods (natural fp) than for fp from cultured copepods. This is not surprising, given the trophic plasticity of benthic copepods allowing them to switch from one food source to another (Hicks \& Coull 1983). These 'internal' fp bacteria must originate from the copepod's gut flora or from transient food bacteria. Long-term rearing of copepods in the laboratory on a single food source resulted in a more constant bacterial community than on fp of copepods from the field. Even for field-caught copepods, a reduction in fp bacterial diversity was found after 1 to $2 \mathrm{~d}$ of laboratory feeding.

Thus, differences in bacterial assemblages on natural fp can be explained by natural variability in the copepod's feeding behavior which, in turn, shapes copepod gut flora. Variability in copepod gut microflora is well known, with resource composition but also host feeding activity and copepod life history as potential regulating factors (Harris 1993, Tang 2005, Grossart et al. 2009, Tang et al. 2009, Cnudde et al. 2011). The food source with its 'microbial coat' delivers bacteria to the gut, which are voided shortly after (transient bacteria), or become part of the gut flora 
(resident bacteria) (Tang et al. 2009, De Troch et al. 2010), or food source ingestion can change bacterial dynamics inside the gut and stimulate bacterial growth of the gut flora (Tang 2005, Tang et al. 2009). Yet, the precise origin of gut bacteria, i.e. transient versus resident, is difficult to establish. The resident gut flora is actually composed of bacteria which are ingested through grazing and/or through 'drinking' of seawater. For copepods reared on Seminavis robusta, the majority of active 'internal' fp bacteria as derived from DGGE band intensity (but not in terms of diversity of OTUs) was related to the food source. Even in field-caught copepods which had been fed $S$. robusta for $24 \mathrm{~h}$, at least one-third of the active 'internal' fp bacteria originated from the food source. This strongly indicates that food bacteria have an immediate signature on the 'internal' bacterial community. This immediate and drastic impact of food on copepod flora explains why we did not find direct evidence of copepod-specific (resident) bacteria in fresh fp. Some genetic diversity of fresh fp bacteria may also originate from copepod exoskeleton bacteria, not only through colonization after fp egestion but through deposition of bacteria positioned around the anus (Carman \& Dobbs 1997) during fp egestion.

Note that some OTUs $($ OTU 7,18$)$ of laboratory fp which we considered to originate from Seminavis robusta were shared with natural fp. These OTUs may represent general diatom-associated bacteria which are not specific for $S$. robusta but also occur on other diatoms. In addition, caution is due when comparing specific OTUs on DGGEs of bacterial communities from different environments, because an OTU can represent more than a single bacterial species. We did not perform repeated sequencing of single bands and can therefore not completely exclude that particular OTUs may have represented more than a single bacterial species.

The presence of a diverse 'internal' active bacterial community in freshly produced $\mathrm{fp}$, independent of their origin (i.e. laboratory or natural), underlines the general occurrence of 'internal' fp degradation. Due to the close link between food source bacteria and copepod bacteria, it is difficult to exactly determine the ratio of transient to resident fp bacteria.

\section{Structural shifts in bacterial communities during fp degradation}

Incubation of $\mathrm{fp}$ in seawater rapidly and drastically changed the active fp bacterial communities (within the first $40 \mathrm{~h}$ ), which is in agreement with the bacterial community shifts on planktonic fp (Jing et al. 2012). However, apart from this rapid early colonization, the study by Jing et al. (2012) conflicts strongly with the present one, as it reports a high significance of bacterial diversity colonizing the copepod fp, while, in the present study, the initial bacterial diversity of fresh $\mathrm{fp}$ was most spectacular and not the added diversity from seawater bacteria. Although no other studies have evaluated the importance of bacterial colonization in terms of diversity, the limited colonization of free-living bacteria from seawater on $\mathrm{fp}$ is in agreement with the results of Gowing \& Silver (1983), who found substantially higher bacterial abundances on the surfaces of laboratory-incubated fp than on those of field-collected planktonic fp. Nevertheless, the number of seawater-derived phylotypes colonizing the fp may have been underestimated for the following reasons. Some common seawater bacteria may regularly be ingested by copepods and thus become part of their gut flora, so that they also end up as 'internal' fp strains. Alternatively, fp colonization may be a selective process in which only certain groups of seawater bacteria participate, but the trigger for bacterial attachment to copepod fp is yet unknown (Jacobsen \& Azam 1984). We can, however, only compare our results with those of planktonic $\mathrm{fp}$, since the bacterial colonization rate for benthic copepod fp has not been studied.

However, during fp aging prominent changes in community structure were related to 'internal' bacteria due to a loss or elevated contribution of certain bacterial phylotypes and shifts in dominance. 'Internal' bacterial phylotypes participated almost equally to the $60 \mathrm{~h}$ aged bacterial community as external phylotypes (based on DGGE band intensity), indicating that 'internal' bacteria were not outperformed by external bacteria. As long as fp matter is tightly packed and surrounded by the peritrophic membrane, 'internal' and invasive external bacteria supposedly easily co-exist (limited competition for resources and space). Moreover, the progeny of attached fp bacteria is released into the seawater (Jacobsen \& Azam 1984, Thor et al. 2003). Poulsen \& Iversen (2008) reported that up to $59 \%$ of the degradation rate of small planktonic copepod fp is due to fp-associated bacteria, but the applied experimental setup was not designed to make a distinction between 'internal' fp bacteria and surface-attached fp bacteria. Most studies report high 'internal' bacterial abundances (Honjo \& Roman 1978, Gowing \& Silver 1983, Jacobsen \& Azam 1984, Tang 2005) and bacterial activity (Olsen et al. 2005, Ploug et al. 2008, Poulsen \& Iversen 2008). 


\section{Functional diversity}

Functionality of specific ecological microbial communities has been deduced from Lorenz curves in multiple studies (Dejonghe et al. 2001, Mertens et al. 2005, Wittebolle et al. 2008). In spite of a genetic shift in bacterial community during fp aging, fp of different ages showed a similar functional organization, characterized by a high level of dominance (Lorenz curves, on average $65 \%$ ), suggesting a specialized community (Marzorati et al. 2008). A stable functional organization could imply functional redundancy (Fernandez et al. 2000). However, dissimilar metabolic potential of fresh fp and aged fp communities (reduced functional diversity; see further on) rather suggests that the concept of functional redundancy is not valid for these environmental bacterial assemblages. Moreover, in the case of fp bacterial communities, community structure is not a good indicator for community functionality. Nevertheless, these results have to be carefully interpreted since DGGE-based diversity estimates may be biased at each single step involved in the molecular analysis (cell lysis, RNA extraction and degradation, PCR amplification and DNA fragment separation) (von Wintzingerode et al. 1997). Furthermore, the additional incubation period of fresh fp to increase bacterial abundances may have affected the bacterial community structure. For example, differential bacterial growth rates among species or complex bacteria-bacteria interactions may yield differences in community composition.

In marine environments, Biolog plates have already successfully been applied for the assessment of bacterial metabolic diversity of, e.g., mollusks (Smith et al. 2001), estuarine bacterioplankton (Schultz \& Ducklow 2000) and marine bacterioplankton (Jellett et al. 1996, Sala et al. 2008). Carbon substrate utilization profiles of such culture-dependent assays do not necessarily reflect the functionality of the community under natural conditions (Smalla et al. 1998), due to the loss of the uncultivable fraction and due to shifts in the composition and density of the remaining fraction. Moreover, Biolog assays measure bacterial metabolic potential under aerobic conditions, while fp bacteria may be primarily facultative anaerobes or microaerophiles (Gowing \& Silver 1983). Typically, the environment that $\mathrm{fp}$ are exposed to after egestion, i.e. the intertidal sediment, is often hypoxic or even anoxic. At the site where Platychelipus was collected, for instance, the oxygen penetration depth in the sediment is ca. $3 \mathrm{~mm}$ (Van Colen et al. 2012). Our laboratory incubations deviated from these in situ conditions by exposing the pellets to oxic conditions.
Therefore, Biolog patterns should be interpreted with caution.

A predominant use of carbohydrates and polymers by external as well as 'internal' fp bacteria suggests that both may be able to degrade the fp peritrophic membrane, which is composed of polysaccharides such as chitin ( $\mathrm{N}$-acetyl-D-glucosamine sugar units) (Ferrante \& Parker 1977, Kirchner 1995). Through the bacterial degradation of the peritrophic membrane and other complex substrates in the fp, carbon and nitrogen are recycled. At first sight, the reduced functional diversity of $60 \mathrm{~h}$ aged fp is unexpected given the increased genetic diversity of active bacteria compared to fresh fp, as shown by our DGGE profiles. This can perhaps be explained by metabolic specialization of the bacterial assemblage on aged $\mathrm{fp}$ and by a low availability of high-quality substrate remaining in $60 \mathrm{~h}$ aged fp. For example, zooplankton fp contain high concentrations of amino acids (Poulet et al. 1986). These amino acids are selectively utilized by marine heterotrophic bacteria (Amano et al. 1982, Bright \& Fletcher 1983), and, in combination with the spontaneous release of dissolved organic matter during $\mathrm{fp}$ aging, fp are rapidly depleted in amino acids, depending on temperature, within 3 to $5 \mathrm{~d}$ (Roy \& Poulet 1990). Reduced functional diversity can also result from a reduced bacterial cell density associated with $60 \mathrm{~h}$ aged $\mathrm{fp}$. It has been reported that bacterial cell abundance diminishes during degradation of diatom-based fp of the planktonic Acartia tonsa (Hansen et al. 1996), but we did not determine bacterial abundances on $\mathrm{fp}$.

The metabolic profiles yield only limited information on the origin of $f p$ bacteria due to the large overlap in substrate utilization between bacteria from Seminavis robusta, copepods and seawater. The common occurrence of Tween 40 utilization by bacteria on $S$. robusta and on fresh and aged fp bacteria, supports the statement that undigested food bacteria may contribute to fp degradation.

The dominant presence of the main groups of Gamma- and Alphaproteobacteria and particularly the strong occurrence of Vibrio sp. on copepod fp are in line with earlier studies describing fp bacterial diversity (Delille \& Razouls 1994, Hansen \& Bech 1996, De Troch et al. 2010, Jing et al. 2012). Although Vibrio sp. is a well-known, free-living seawater bacterium, some of these studies showed their enriched presence on copepod fp. Based on the high number of different OTUs retrieved from the fp Biolog assays and identified as Vibrio sp., our findings suggest their primary contribution to the observed substrate utilization pattern and thus their general importance to the fp degradation process. 


\section{CONCLUSION}

Based on bacterial community dynamics, this study proves the significant role of 'internal' bacteria to fp degradation compared to bacteria which colonize fp from the outside. 'Internal' bacterial diversity is variable but significantly contributes to the total bacterial diversity of aging $\mathrm{fp}$. 'Internal' fp bacteria include ingested food-associated bacteria, copepod gut bacteria and probably seawater bacteria. Copepod diet is the overall regulator of $\mathrm{fp}$ 'internal' bacteria: it delivers active bacteria directly to the $\mathrm{fp}$, and, indirectly, it shapes the copepod gut flora. Hence, fp degradation by 'internal' bacteria may vary with copepod feeding ecology. Exterior colonization by ambient seawater bacteria occurred rapidly but by a rather limited number of bacterial phylotypes. Freeliving seawater bacteria but also 'internal' fp bacteria are able to utilize a wide range of substrates, primarily carbohydrates and polymers. In terms of bacterial diversity and functional potential, there is little reason to believe that bacterial degradation of copepod $\mathrm{fp}$ on the interior is inferior to degradation from the outside.

Acknowledgements. The first author acknowledges a $\mathrm{PhD}$ grant from the IWT (Institute for the Promotion of Innovation through Science and Technology in Flanders). M.D.T. is a postdoctoral researcher financed by the Special Research Fund at Ghent University (GOA Project 01GA1911W). Financial support was obtained from the Flemish Science Foundation through Project 3G019209W and from the research council of Ghent University through Project 0110600002 . We thank Annelien Rigaux (Marine Biology) for her assistance with the labor-intensive purification of DGGE bands.

\section{LITERATURE CITED}

Amano M, Hara S, Taga N (1982) Utilization of dissolved amino acids in seawater by marine bacteria. Mar Biol 68: 31-36

Anderson IC, Parkin PI (2007) Detection of active soil fungi by RT-PCR amplification of precursor rRNA molecules. J Microbiol Methods 68:248-253

$>$ Anderson TR, Tang KW (2010) Carbon cycling and POC turnover in the mesopelagic zone of the ocean: insights from a simple model. Deep-Sea Res II 57:1581-1592

Anderson M, Gorley R, Clarke K (2008) PERMANOVA+ for PRIMER: guide to software and statistical methods. PRIMER-E, Plymouth

Baele M, Baele P, Vaneechoutte M, Storms V and others (2000) Application of tRNA intergenic spacer PCR for identification of Enterococcus species. J Clin Microbiol 38:4201-4207

Bright JJ, Fletcher M (1983) Amino acid assimilation and respiration by attached and free-living populations of a marine Pseudomonas sp. Microb Ecol 9:215-226
Carman KR, Dobbs FC (1997) Epibiotic microorganisms on copepods and other marine crustaceans. Microsc Res Tech 37:116-135

$>$ Cho BC, Azam F (1988) Major role of bacteria in biochemical fluxes in the oceans interior. Nature 332:441-443

Clarke K, Gorley R (2006) Primer v6: user manual/tutorial. Primer-E, Plymouth

- Cnudde C, Willems A, Van Hoorde K, Vyverman W, Moens T, De Troch M (2011) Effect of food preservation on the grazing behavior and on the gut flora of the harpacticoid copepod Paramphiascella fulvofasciata. J Exp Mar Biol Ecol 407:63-69

> De Troch M, Cnudde C, Vyverman W, Vanreusel A (2009) Increased production of faecal pellets by the benthic harpacticoid Paramphiascella fulvofasciata: importance of the food source. Mar Biol 156:469-477

> De Troch M, Cnudde C, Willems A, Moens T, Vanreusel A (2010) Bacterial colonization on fecal pellets of harpacticoid copepods and on their diatom food. Microb Ecol 60: 581-591

Dejonghe W, Boon N, Seghers D, Top EM, Verstraete W (2001) Bioaugmentation of soils by increasing microbial richness: missing links. Environ Microbiol 3:649-657

Delille D, Razouls S (1994) Community structures of heterotrophic bacteria of copepod fecal pellets. J Plankton Res 16:603-615

Don RH, Cox PT, Wainwright BJ, Baker K, Mattick JS (1991) Touchdown PCR to circumvent spurious priming during gene amplification. Nucleic Acids Res 19:4008

> Fernandez AS, Hashsham SA, Dollhopf SL, Raskin L and others (2000) Flexible community structure correlates with stable community function in methanogenic bioreactor communities perturbed by glucose. Appl Environ Microbiol 66:4058-4067

> Ferrante JG, Parker JI (1977) Transport of diatom frustules by copepod fecal pellets to sediments of Lake Michigan. Limnol Oceanogr 22:92-98

> Fukami K, Simidu U, Taga N (1981) Fluctuation of the communities of heterotrophic bacteria during the decomposition process of phytoplankton. J Exp Mar Biol Ecol 55: 171-184

- Garland JL (1996) Analytical approaches to the characterization of samples of microbial communities using patterns of potential C source utilization. Soil Biol Biochem 28:213-221

> Garland JL, Lehman RM (1999) Dilution/extinction of community phenotypic characters to estimate relative structural diversity in mixed communities. FEMS Microbiol Ecol 30:333-343

Garland JL, Mills AL (1991) Classification and characterization of heterotrophic microbial communities on the basis of patterns of community-level sole-carbon-source utilisation. Appl Environ Microbiol 57:2351-2359

Gowing MM, Silver MW (1983) Origins and microenvironments of bacteria mediating fecal pellet decomposition in the sea. Mar Biol 73:7-16

Grossart HP, Dziallas C, Tang KW (2009) Bacterial diversity associated with freshwater zooplankton. Environ Microbiol Rep 1:50-55

Guillard RRL (1975) Culture of phytoplankton for feeding marine invertebrates. In: Smith W, Chandley M (eds) Culture of marine invertebrate animals. Plenum Press, New York, NY

Hansen B, Bech G (1996) Bacteria associated with a marine planktonic copepod in culture. I. Bacterial genera in sea- 
water, body surface, intestines and fecal pellets and succession during fecal pellet degradation. J Plankton Res 18:257-273

> Hansen B, Fotel FL, Jensen NJ, Madsen SD (1996) Bacteria associated with a marine planktonic copepod in culture. II. Degradation of fecal pellets produced on a diatom, a nanoflagellate or a dinoflagellate diet. J Plankton Res 18: 275-288

> Harris JM (1993) The presence, nature, and role of gut microflora in aquatic invertebrates: a synthesis. Microb Ecol 25:195-231

Hicks GRF, Coull BC (1983) The ecology of marine meiobenthic harpacticoid copepods. Oceanogr Mar Biol Annu Rev 21:67-175

> Honjo S (1976) Coccoliths - production, transportation and sedimentation. Mar Micropaleontol 1:65-79

Honjo S, Roman MR (1978) Marine copepod fecal pellets production, preservation and sedimentation. J Mar Res 36:45-57

> Insam H (1997) Substrate utilization tests in microbial ecology - A preface to the special issue of the Journal of Microbiological Methods. J Microbiol Methods 30:1-2

> Iversen M, Poulsen LK (2007) Coprohexy, coprophagy, and coprochaly in the copepods Calanus helgolandicus, Pseudocalanus elongatus, and Oithona similis. Mar Ecol Prog Ser 350:79-89

Jacobsen TR, Azam F (1984) Role of bacteria in copepod fecal pellet decomposition: colonization, growth-rates and mineralization. Bull Mar Sci 35:495-502

> Jellett JF, Li WKW, Dickie PM, Boraie A, Kepkay PE (1996) Metabolic activity of bacterioplankton communities assessed by flow cytometry and single carbon substrate utilization. Mar Ecol Prog Ser 136:213-225

> Jing H, Shek L, Yung W, Jin X, Liu H (2012) Dynamics of bacterial community composition during degradation of copepod fecal pellets. J Plankton Res 34:700-710

> Johannes RE, Satomi M (1966) Composition and nutritive value of fecal pellets of a marine crustacean. Limnol Oceanogr 11:191-197

> Jumars PA, Penry DL, Baross JA, Perry MJ, Frost BW (1989) Closing the microbial loop - Dissolved carbon pathway to heterotrophic bacteria from incomplete ingestion, digestion and absorption in animals. Deep-Sea Res Part A 36:483-495

Kerkhof L, Ward BB (1993) Comparison of nucleic-acid hybridization and fluorometry for measurement of the relationship between RNA/DNA ratio and growth-rate in a marine bacterium. Appl Environ Microbiol 59: 1303-1309

Kirchner M (1995) Microbial colonization of copepod body surfaces and chitin degradation in the sea. Helgol Meeresunters 49:201-212

Koski M, Kiørboe T, Takahashi K (2005) Benthic life in the pelagic: aggregate encounter and degradation rates by pelagic harpacticoid copepods. Limnol Oceanogr 50: 1254-1263

Lawrence SG, Ahmad A, Azam F (1993) Fate of particlebound bacteria ingested by Calanus pacificus. Mar Ecol Prog Ser 97:299-307

Lorenz MO (1905) Methods of measuring concentration of wealth. J Am Stat Assoc 9:209-219

Marzorati M, Wittebolle L, Boon N, Daffonchio D, Verstraete W (2008) How to get more out of molecular fingerprints: practical tools for microbial ecology. Environ Microbiol 10:1571-1581
Mertens B, Boon N, Verstraete W (2005) Stereospecific effect of hexachlorocyclohexane on activity and structure of soil methanotrophic communities. Environ Microbiol 7:660-669

> Milner MG, Saunders JR, McCarthy AJ (2001) Relationship between nucleic acid ratios and growth in Listeria monocytogenes. Microbiology 147:2689-2696

> Møller EF, Thor P, Nielsen TG (2003) Production of DOC by Calanus finmarchicus, C. glacialis and C. hyperboreus through sloppy feeding and leakage from fecal pellets. Mar Ecol Prog Ser 262:185-191

> Møller EF, Borg CMA, Jónasdóttir SH, Satapoomin S, Jaspers C, Nielsen TG (2011) Production and fate of copepod fecal pellets across the southern Indian Ocean. Mar Biol 158:677-688

Morales CE (1987) Carbon and nitrogen content of copepod fecal pellets: effect of food concentration and feeding behavior. Mar Ecol Prog Ser 36:107-114

- Nair A, Ngouajio M (2012) Soil microbial biomass, functional microbial diversity, and nematode community structure as affected by cover crops and compost in an organic vegetable production system. Appl Soil Ecol 58: 45-55

Noji TT, Estep KW, Macintyre F, Norrbin F (1991) Imageanalysis of fecal material grazed upon by 3 species of copepods: evidence for coprorhexy, coprophagy and coprochaly. J Mar Biol Assoc UK 71:465-480

> Olesen M, Strake S, Andrushaitis A (2005) Egestion of nonpellet-bound fecal material from the copepod Acartia tonsa: implication for vertical flux and degradation. Mar Ecol Prog Ser 293:131-142

> Olsen SN, Westh P, Hansen BW (2005) Real-time quantification of microbial degradation of copepod fecal pellets monitored by isothermal microcalorimetry. Aquat Microb Ecol 40:259-267

> Ploug H, Iversen MH, Fischer G (2008) Ballast, sinking velocity, and apparent diffusivity within marine snow and zooplankton fecal pellets: implications for substrate turnover by attached bacteria. Limnol Oceanogr 53: 1878-1886

Poulet SA, Harris RP, Martinjezequel V, Moal J, Samain JF (1986) Free amino-acids in copepod fecal pellets. Oceanol Acta 9:191-197

Poulsen LK, Iversen MH (2008) Degradation of copepod fecal pellets: key role of protozooplankton. Mar Ecol Prog Ser 367:1-13

Poulsen LK, Kiørboe T (2005) Coprophagy and coprorhexy in the copepods Acartia tonsa and Temora longicornis: clearance rates and feeding behaviour. Mar Ecol Prog Ser 299:217-227

> Preston-Mafham J, Boddy L, Randerson PF (2002) Analysis of microbial community functional diversity using solecarbon-source utilisation profiles - a critique. FEMS Microbiol Ecol 42:1-14

R Development Core Team (2012) R: a language and environment for statistical computing. $\mathrm{R}$ Foundation for Statistical Computing, Vienna

Reigstad M, Riser CW, Svensen C (2005) Fate of copepod faecal pellets and the role of Oithona spp. Mar Ecol Prog Ser 304:265-270

> Roy S, Poulet SA (1990) Laboratory study of the chemical composition of aging copepod fecal material. J Exp Mar Biol Ecol 135:3-18

Sala MM, Terrado R, Lovejoy C, Unrein F, Pedros-Alio C (2008) Metabolic diversity of heterotrophic bacterio- 
plankton over winter and spring in the coastal Arctic Ocean. Environ Microbiol 10:942-949

Schultz GE, Ducklow H (2000) Changes in bacterioplankton metabolic capabilities along a salinity gradient in the York River estuary, Virginia, USA. Aquat Microb Ecol 22: 163-174

Smalla K, Wachtendorf U, Heuer H, Liu WT, Forney L (1998) Analysis of BIOLOG GN substrate utilization patterns by microbial communities. Appl Environ Microbiol 64: 1220-1225

Smetacek VS (1980) Zooplankton standing stock, copepod fecal pellets and particulate detritus in Kiel Bight. Estuar Coast Mar Sci 11:477-490

Smith EA, Grant F, Ferguson CMJ, Gallacher S (2001) Biotransformations of paralytic shellfish toxins by bacteria isolated from bivalve molluscs. Appl Environ Microbiol 67:2345-2353

Tang KW (2001) Defecation of dimethylsulfoniopropionate (DMSP) by the copepod Acartia tonsa as functions of ambient food concentration and body DMSP content. J Plankton Res 23:549-553

Tang KW (2005) Copepods as microbial hotspots in the ocean: effects of host feeding activities on attached bacteria. Aquat Microb Ecol 38:31-40

Tang KW, Visscher PT, Dam HG (2001) DMSP-consuming bacteria associated with the calanoid copepod Acartia tonsa (Dana). J Exp Mar Biol Ecol 256:185-198

Tang K, Dziallas C, Hutalle-Schmelzer K, Grossart HP (2009) Effects of food on bacterial community composition associated with the copepod Acartia tonsa Dana. Biol Lett 5:549-553

Temmerman R, Scheirlinck I, Huys G, Swings J (2003) Culture-independent analysis of probiotic products by denaturing gradient gel electrophoresis. Appl Environ Microbiol 69:220-226

Thor P, Dam HG, Rogers DR (2003) Fate of organic carbon released from decomposing copepod fecal pellets in relation to bacterial production and ectoenzymatic activity. Aquat Microb Ecol 33:279-288

Thor P, Koski M, Tang KW, Jónasdóttir SH (2007) Supplemental effects of diet mixing on absorption of ingested organic carbon in the marine copepod Acartia tonsa. Mar

Editorial responsibility: Urania Christaki, Wimereux, France
Ecol Prog Ser 331:131-138

> Turner JT (1979) Microbial attachment to copepod fecal pellets and its possible ecological significance. Trans Am Microsc Soc 98:131-135

> Turner JT (2002) Zooplankton fecal pellets, marine snow and sinking phytoplankton blooms. Aquat Microb Ecol 27:57-102

Urban-Rich J, Nordby E, Andreassen IJ, Wassmann P (1999) Contribution by mesozooplankton fecal pellets to the carbon flux on Nordvestbanken, north Norwegian shelf in 1994. Sarsia 84:253-264

- Van Colen C, Rossi F, Montserrat F, Andersson MGI and others (2012) Organism-sediment interactions govern post-hypoxia recovery of ecosystem functioning. PLoS ONE 7:e49795

von Wintzingerode F, Gobel UB, Stackebrandt E (1997) Determination of microbial diversity in environmental samples: pitfalls of PCR-based rRNA analysis. FEMS Microbiol Rev 21:213-229

Wassmann P, Hansen L, Andreassen IJ, Riser CW, UrbanRich J (1999) Distribution and sedimentation of faecal pellets on the Nordvestbanken shelf, northern Norway, in 1994. Sarsia 84:239-252

Wexels Riser C, Reigstad M, Wassmann P, Arashkevich E, Falk-Petersen S (2007) Export or retention? Copepod abundance, faecal pellet production and vertical flux in the marginal ice zone through snap shots from the northern Barents Sea. Polar Biol 30:719-730

Wittebolle L, Vervaeren H, Verstraete W, Boon N (2008) Quantifying community dynamics of nitrifiers in functionally stable reactors. Appl Environ Microbiol 74: 286-293

> Wright ES, Yilmaz LS, Noguera DR (2012) DECIPHER, a search-based approach to chimera identification for $16 \mathrm{~S}$ rRNA sequences. Appl Environ Microbiol 78:717-725

Yu Z, Morrison M (2004) Comparisons of different hypervariable regions of rrs genes for use in fingerprinting of microbial communities by PCR-denaturing gradient gel electrophoresis. Appl Environ Microbiol 70:4800-4806

> Zak JC, Willig MR, Moorhead DL, Wildman HG (1994) Functional diversity of microbial communities: a quantitative approach. Soil Biol Biochem 26:1101-1108

Submitted: April 15, 2013; Accepted: September 13, 2013 Proofs received from author(s): November 11, 2013 